\begin{tabular}{c|c|c}
\hline \hline $\begin{array}{c}\text { Vol. 34(3):305-323 } \\
\text { http://dx.doi.org/10.4217/OPR.2012.34.3.305 }\end{array}$ & Ocean and Polar Research & September 2012 \\
\hline \hline
\end{tabular}

Article

\title{
Ocean Response to the Pinatubo and 1259 Volcanic Eruptions
}

\author{
Seong-Joong Kim* and Baek-Min Kim \\ Korea Polar Research Institute, KIOST \\ Incheon 406-840, Korea
}

\begin{abstract}
The ocean's response to the Pinatubo and 1259 volcanic eruptions was investigated using an ocean general circulation model equipped with an energy balance model. Volcanic eruptions release gases into the atmosphere which increases the aerosol optical depth and acts to reduce the incoming short-wave radiation. For example, there was a huge volcanic eruption (Pinatubo) in 1991 which reduced the global mean radiative forcing by about $3 \mathrm{~W} \mathrm{~m}^{-2}$. Two numerical experiments were simulated. The first experiment features the Pinatubo eruption and the second experiment simulates the much larger volcanic eruption that occurred in 1259 when the radiative forcing was reduced by 7 times compared to the Pinatubo event. With the reduced radiative forcing due to the Pinatubo eruption at about $3 \mathrm{~W} \mathrm{~m}^{-2}$ and 1259 eruption at about $21 \mathrm{~W} \mathrm{~m}^{-2}$, the global mean sea surface temperature (SST) decreased to its lowest in the second year after each event by about $0.4^{\circ} \mathrm{C}$ and $1.6^{\circ} \mathrm{C}$, respectively. Sea surface salinity (SSS) increased substantially in the northern North Pacific, northern North Atlantic, and the Southern Ocean. The reduced SST together with SSS increased ocean convection, which yielded an increase in North Atlantic Deep Water, Antarctic Bottom Water, and North Pacific Intermediate Water production and their outflows. The increase in overturning circulation eventually increased the pole-ward ocean heat fluxes. In conclusion, huge volcanic eruptions perturb the ocean substantially and their hallmarks last for more than a decade, confirming the importance of volcanic eruptions in illustrating the decadal-climate variability recorded in the paleoclimate proxy data for the past million years.
\end{abstract}

Key words : volcanic eruption, Pinatubo, surface cooling, ocean temperature, salinity

\section{Introduction}

The surface temperature declined by about $0.2^{\circ} \mathrm{C}$ over the past millennium in the northern hemisphere until the industrial revolution (about year 1850) (Mann et al. 1999, 2009; Crowley and Lowery 2000; Briffa 2000; Mann et al. 2009), but since then the earth's surface temperature has risen rapidly and for the past century and the globally averaged surface temperature for the earth has increased by $0.7^{\circ} \mathrm{C}$ (IPCC 2007). By analyzing the climate data over the past millennium, it is obvious that recent climate change far exceeds natural variability.

The long-term surface cooling during the past millennium prior to industrialization is related to astronomical forcing, while other centennial and multi-decadal scale variabilities

\footnotetext{
*Corresponding author. E-mail : seongjkim@kopri.re.kr
}

are associated with Solar Irradiance variations and volcanic eruptions. Note that during the pre-industrial period, the change in atmospheric $\mathrm{CO}_{2}$ was negligible and atmosphereocean interaction played a marginal role. Using an energy balance model, Crowley (2000) concluded that the 41$64 \%$ of pre-anthropogenic low-frequency temperature variability is accounted for by volcanism and solar variability. Solar variations involve multi-decadal variability, but their radiative forcing is about 100 times smaller than those of volcanic eruptions. Decadal-scale climate variability during the Little Ice Age (about 1300-1890) is largely illustrated by pulses of volcanism (Porter 1986; Briffa et al. 1998; Mann et al. 1998, 2009). However, the illustration of the decadal climate variability by volcanic eruption is puzzling because the e-folding time for the reduction of stratospheric aerosols of volcanic origin is about one year even for a very large volcanic eruption and the erupted aerosol levels 
return to normal within two years. The ocean might be a candidate for adjusting the decadal-scale climate variability because the ocean plays an important role in the global climate system by distributing and storing heat. To adjust the heat imbalance between the tropics and the poles, about $6 \mathrm{PW}\left(1 \mathrm{PW}=1 \times 10^{15} \mathrm{~W}\right)$ of heat is transferred to high latitudes by the atmosphere and ocean. About twothirds of the total pole ward heat is transported by the atmosphere and the rest is carried by the ocean (Trenberth and Caron 2001). In response to a change in external forcing, thus, it takes much longer time for the ocean to adjust than the atmosphere due to its much larger heat capacity.

There have been many studies on the effect of volcanic eruptions on global climate change (Robock 2000; Stenchikov et al. 1998, 2002, 2004, 2009; Kirchner et al. 1999; Yang and Schlesinger 2002; Shindell et al. 2004; Gleckler et al. 2006; Frölicher et al. 2011; Mignot et al. 2011; Ottera et al. 2010; Zanchettin et al. 2012). The studies showed that large volcanic eruptions emit sulphur gases into the stratosphere, which become sulphate aerosols. The aerosols cool the surface by scattering some solar radiation back to space, whereas they heat the stratosphere by absorbing both solar and terrestrial radiation. When there is a volcanic eruption in the tropics, the greater heating in the stratosphere than in high latitudes leads to an enhanced equator-to-pole temperature gradient, which produces a stronger polar vortex. This results in the winter warming of northern hemisphere continents. From numerous studies on the effect of volcanic eruptions on global climate change, the change in surface response is relatively well known. Several studies have been conducted to examine the response of the ocean to volcanic eruptions (e.g., Jones et al. 2005; Gleckler et al. 2006; Stenchikov et al. 2009; Mignot et al. 2011; Ottera et al. 2010; Zanchettin et al. 2012). However, the effect of volcanic eruption on the ocean and its feedback on climate change remains unclear. Moreover, oceanic thermohaline properties and circulations have not been thoroughly studied. The objective of this study was to investigate the response of ocean to the reduction in radiative forcing due to volcanic eruptions.

\section{Numerical Model and Experiments}

\section{Numerical model}

This study employs an ocean general circulation model equipped with an energy balance model. The ocean model is the Hamburg Large Scale Geostrophic (LSG) Ocean General Circulation model developed at the Max-Planck
Institute (Maier-Reimer et al. 1993). The model version used in this study is global with an effective horizontal resolution of $3.5^{\circ}$. It has 22 vertical layers with top layer thickness of $50 \mathrm{~m}$. The equations are discretized on an Arakawa E grid (Arakawa and Lamb 1977), i.e., the model grid consists of two C-grids staggered to one another. The model includes 'real' bottom topography and the free surface is treated prognostically. The model includes a simple dynamic-thermodynamic sea ice model. The sea-ice is advected by both ocean currents and winds. Convective mixing is applied whenever the stratification becomes unstable.

The atmospheric component is the two dimensional energy balance model of North et al. (1983). It assumes a balance between incoming solar radiation with an albedo as a function of surface temperature, outgoing long wave radiation proportional to $\mathrm{T}^{4}$, and atmosphere-ocean heat exchange with a coupling coefficient of $400 \mathrm{~W} \mathrm{~m}^{-2} \mathrm{~K}^{-1}$ to give realistically strong damping. Where there is sea ice, this coupling is reduced. In the case of land temperatures below freezing, snow cover is assumed. With decreasing temperatures, the fraction of land covered by snow increases, and the albedo gradually approaches a value of 0.85 . The atmosphere model is integrated for 1 day and provides heat fluxes to the ocean and then the oceanic mixed layer is integrated for 1 day. No heat flux correction is applied. The freshwater flux is applied with values obtained from spin-up integration. In addition to the freshwater flux, surface salinity is restored to observed climatology from Levitus (1982). The ocean is forced by the seasonal climatological wind stress from the Hellerman and Rosenstein (1983).

\section{Feedback between atmosphere and ocean models}

In the atmospheric component of the model, the energy and moisture balance is estimated. In the moisture balance, the amount of precipitation and evaporation is crudely estimated. Subsequently, the precipitation and evaporation are used in the estimation of the long wave and latent heat fluxes, which is a function of evaporation. In the estimation of the evaporation, oceanic SST is used to calculate the humidity over the ocean. Thus, ocean surface temperature change influences the change in atmosphere heat fluxes. However, note that precipitation is not used in the calculation of salinity because the precipitation distribution for the simple moisture balance model is not good at reproducing surface salinity. Overall, there is energy feedback between the atmosphere and ocean in this particular model. 
(a) Optical thickness at $550 \mathrm{~nm}$

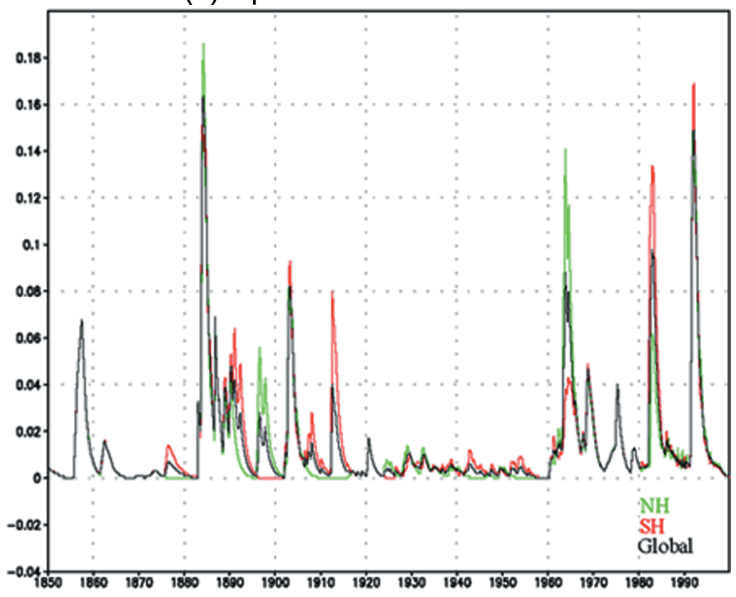

(b) Global-mean radiative forcing

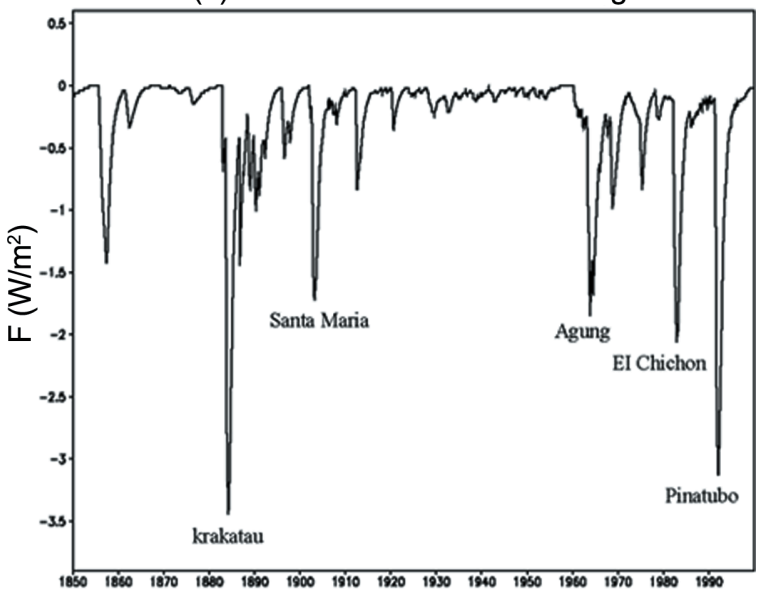

(c) Global-mean radiative forcing

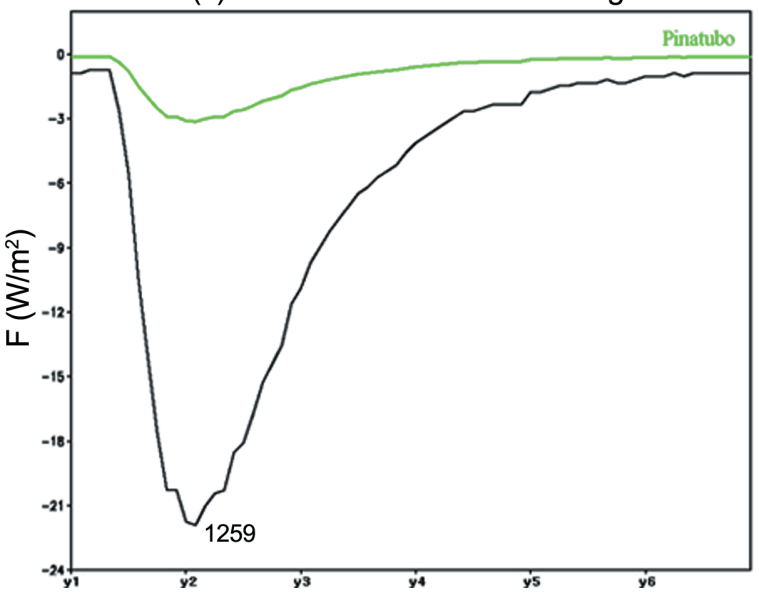

Fig. 1. (a) Global and hemispheric mean stratospheric aerosol optical depth at wavelength $550 \mathrm{~nm}$, (b) global mean radiative forcing change due to volcanic eruptions since year 1850, (c) global mean radiative forcing change for the Pinatubo that occurred in 1991 and the 1259 volcanic eruption. In the $x$-axis, $y 1$ represents the year of volcanic eruption

\section{Experimental design}

There have been many volcanic eruptions over the past millennium. Since industrialization began, the largest volcanic eruption that had a global influence was the Krakatau eruption in Indonesia in 1883 and the second largest was the Pinatubo eruption in Luzon, Philippines in 1991 (Fig. 1). Other eruptions such as the Santa Maria, Guatemala in 1902, the Agung, 1963, Indonesia, and the Elchichon, Mexico in 1982 were also big, but their impacts were rather hemispheric. The erupted gases and aerosols emitted into the stratosphere are measured as optical thickness (Fig. 1a), which is subsequently converted to radiative forcing (Fig. 1b). For a globally uniform stratospheric aerosol layer with an optical depth 1 at $0.55 \mu \mathrm{m}$ yields a forcing of $2.1 \mathrm{~W} \mathrm{~m}^{-2}$ according to Sato et al. (1993). The peak global mean forcing was approximately $-3 \mathrm{~W} \mathrm{~m}^{-2}$ after the Pinatubo eruption, about $-3.5 \mathrm{~W} \mathrm{~m}^{-2}$ after the Krakatau eruption, and approximately $-2 \mathrm{~W} \mathrm{~m}^{-2}$ after Agung and El Chichon. There was a much greater degree of volcanic eruption in 1259 when the radiative forcing change was about $21 \mathrm{~W} \mathrm{~m}^{-2}$ (Crowley 2000).

In this study, two volcanic eruption events were implemented in the LSG/EBM model. In the first experiment, the radiative forcing change due to the Pinatubo eruption was applied, while in the second experiment the radiative forcing change for the largest volcanic eruption over the past millennium that occurred in 1259 was implemented. The perturbation scenario is presented in Fig. 1c.

\section{Results and Discussion}

The reference experiment referred to as REF was integrated for 6000 years with present boundary conditions. With the radiative forcing conditions mentioned in Fig. $1 \mathrm{c}$, the model was run for 100 years starting from the end of the control run. As shown later, the atmosphere responds rather quickly - within several years, but the perturbed signals in the ocean remain for several years to decades, which might consequently influence the global climate. Before we described the response of the ocean to volcanic eruptions, we investigated the ocean model's performance in reproducing the present climate.

\section{Reference experiment}

The vertical distribution of Atlantic temperature and salinity simulated in the REF experiments was compared with the observations of Levitus and Boyer (1994) and Levitus et al. (1994) in Fig. 2. The LSG/EBM model reproduces the vertical temperature distribution to a 
reasonable degree despite the coarse model resolution.

Nevertheless, the deep ocean temperature is too warm and the isotherm is overall too zonal and the surface temperature is overall slightly warmer. This discrepancy is (a) Temperature (Atlantic, Levitus)

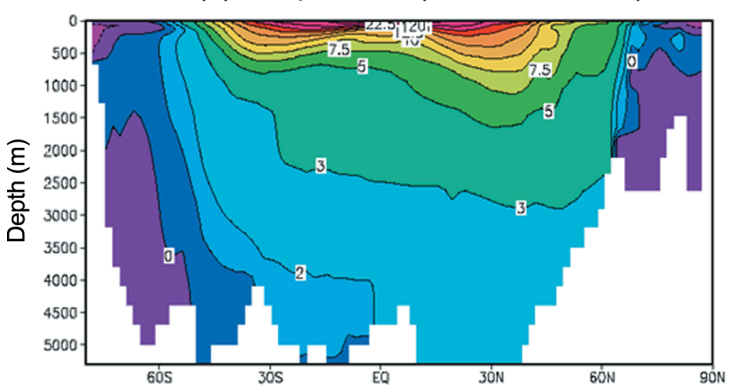

(c) Salinity (Atlantic, Levitus)

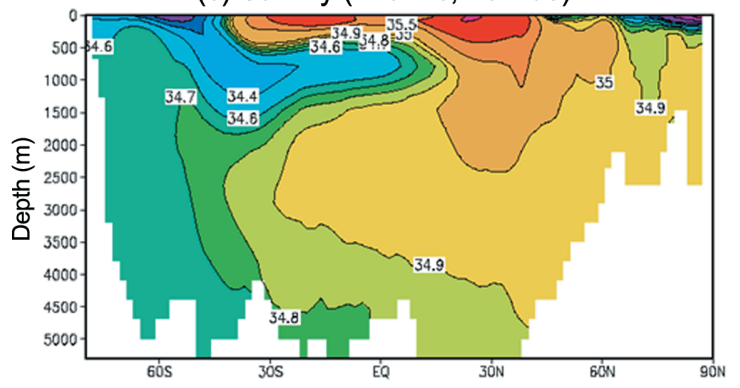

(b) Temperature (Atlantic, REF)

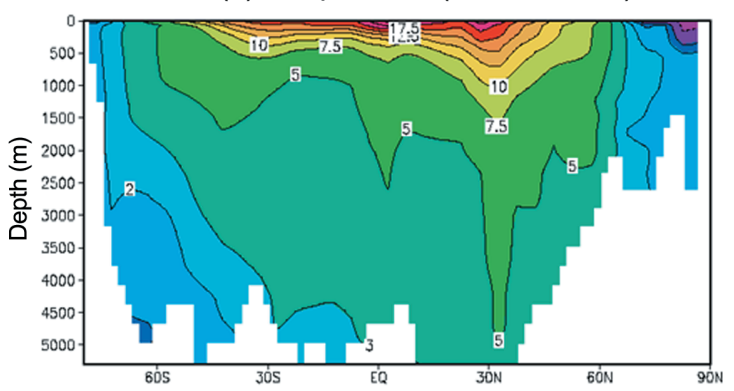

(d) Salinity (Atlantic, REF)

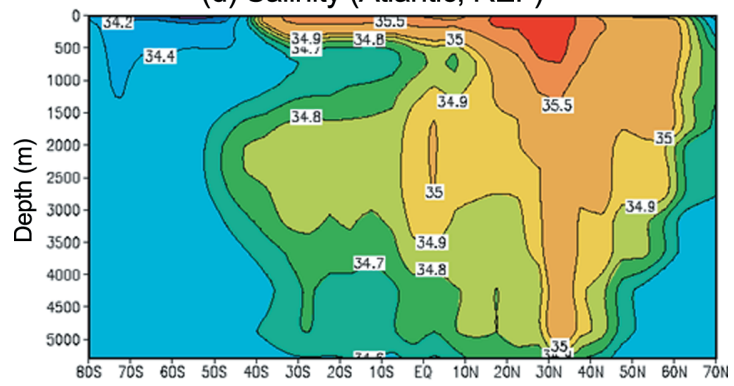

Fig. 2. (a) Vertical distribution averaged over the Atlantic Oceans of the temperature for the (a) observed and (b) simulated in the reference experiment, and the salinity for the (c) observed and (d) simulated in the reference experiment (REF). The observed data are from Levitus (1994)

(a) Surface currents

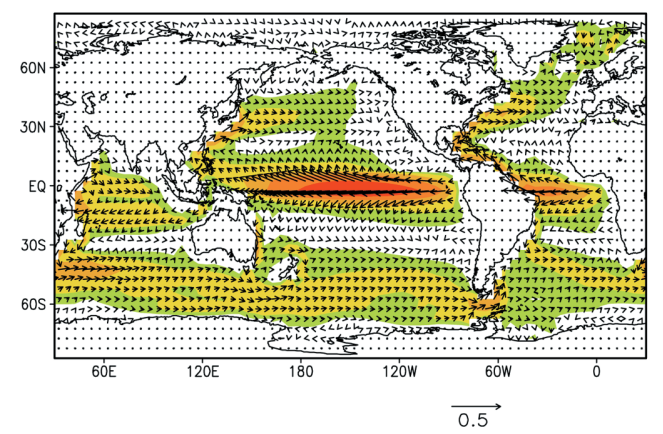

(c) Sea surface height

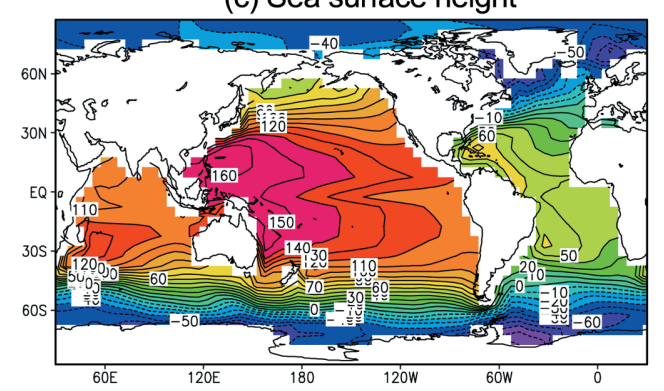

(b) Currents at $3000 \mathrm{~m}$
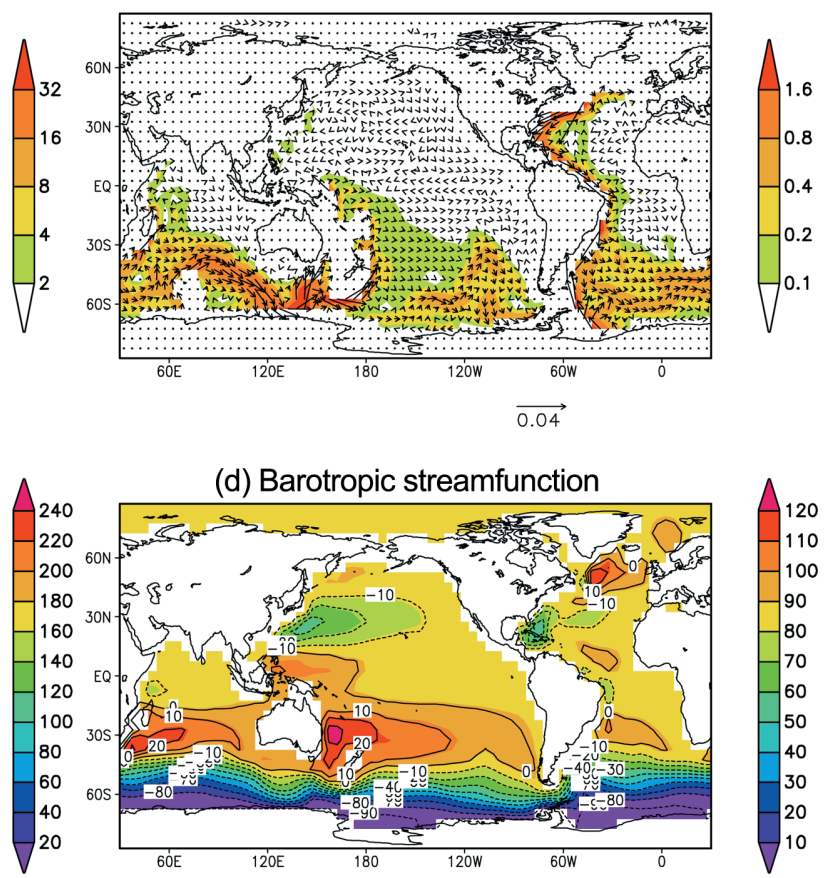

(d) Barotropic streamfunction

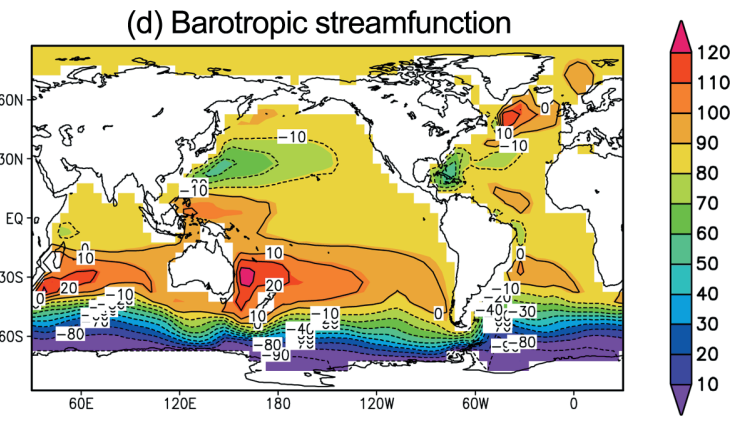

Fig. 3. Geographic distribution of (a) surface currents, (b) currents at $3000 \mathrm{~m}$, (c) sea surface height, and (d) barotropic streamfunction. Units are in $\mathrm{ms}^{-1}$ for currents, meter for sea surface height, and $\mathrm{Sv}\left(1 \times 10^{6} \mathrm{~m}^{3} \mathrm{~s}^{-1}\right)$ for streamfunction simulated in the REF experiment 
presumably due to the relatively simple treatment of atmospheric temperature and heat flux. The reproduction of the vertical distribution for temperature and salinity is even more challenging due to the difficulty in representing the subtle balance of ocean stratification in high latitudes. The deep ocean is comprised of two distinct water masses: relatively warm and saline North Atlantic Deep Water (NADW) and relatively cold and fresh Antarctic Bottom Water (AABW) (Fig. 2a). Above the deep waters, relatively fresh Antarctic Intermediate Water (AAIW) and North Pacific Intermediate Water (NPIW) are present. In the simulation, the features found in observation are roughly captured. However, the temperature is warmer, and salinity is overall fresher, especially in the southern hemisphere such as the fresh tongues of AAIW and NPIW (Fig. 2b), but the AAIW tongue is much less pronounced than in the observation.

Fig. 3 displays the geographic distribution of the annual mean surface and deep currents at $3000 \mathrm{~m}$, sea surface height, and vertically integrated barotropic streamfunction simulated in the REF experiment. In the surface ocean circulation, a marked feature is the strong equatorial currents with current speeds larger than $30 \mathrm{~m} \mathrm{~s}^{-1}$ in the equatorial Pacific, which is coincident with observations from drifters (Maximenko et al. 2009). Kuroshio currents in the North Pacific and the Gulf Stream in the North Atlantic are visible with stronger currents, but their speed is underestimated in comparison to observations. The eastward Antarctic Circumpolar Current (ACC) in the SO is captured, but its speed is underestimated. In the Atlantic Ocean, the deep currents flow southward until they reach Argentina along the western boundary, associated with the southward propagation of NADW. In the SO, the deep ocean currents move eastward as a part of the ACC and northward western boundary currents are obtained in all ocean sectors associated with the propagation of SO water masses.

The sea surface height is higher in the western equatorial Pacific and lower in the eastern Pacific and at higher latitudes (Fig. 3c), as would be expected from the high sea surface temperature distribution. The sea surface height represents the geostrophic currents at the ocean surface parallel to the contours. The narrower the contour intervals are, the faster the geostrophic currents are. The simulated sea surface height is overall consistent with the measured topography using satellite altimeter (Niiler et al. 2003; Maximenko et al. 2009). The vertically integrated barotropic streamfunction shows the simulated Gulf Stream and Kuroshio Current transports of 20 and $30 \mathrm{~Sv}\left(10^{6} \mathrm{~m}^{3} \mathrm{~s}^{-1}\right)$, respectively. These values are underestimated in comparison to observations even though observations are highly uncertain. The Indonesian Throughflow, which is a significant component in the oceanic meridional heat transport as part of 'warm-water route' (Gordon 1986), is about $10 \mathrm{~Sv}$ in REF. This value is within the uncertainty range of observational estimates (e.g., 10-20 Sv from Fieux et al. 1994; Lukas et al. 1996). The simulated Antarctic Circumpolar Current transport simulated is about $90 \mathrm{~Sv}$ at the Drake Passage, which is too weak compared to the observed estimates (e.g., 120-140 Sv from Whitworth and Peterson 1985; Read and Pollard 1993; Macdonald and Wunsch 1996).

Fig. 4 presents the meridional overturning streamfunctions zonally integrated for the global, Atlantic, Pacific basins and oceanic merdional heat transport simulated in the REF experiment. The positive and negative contours represent clockwise and counterclockwise circulations, respectively, and the shading represents the magnitude of the circulation. In the global domain, the meridional overturning circulation with the large positive cell in the northern hemisphere is mainly associated with NADW production and its outflow in the Atlantic Ocean, while the negative cell in the southern high latitudes represents the production of AABW (Fig. 4a). The simulated AABW formation reaching about $3000 \mathrm{~m}$ is about $14 \mathrm{~Sv}$, which is within the uncertainty ranges of observed estimates $(\sim 5$ 10 Sv from Carmack 1977; 8 Sv from Orsi et al. 1999). Another negative cell below $3000 \mathrm{~m}$ is associated with the outflow of water masses from the SO to all ocean basins as shown in other figures.

The simulated North Atlantic overturning streamfunction associated with NADW production is about $30 \mathrm{~Sv}$ (Fig. 4b), which is substantially larger than observationallybased estimates ( 15 Sv Ganachaud and Wunsch 2000). The observed NADW outflow tends to decrease slightly toward the south due to the entrainment of underlying water mass. For example, at $30^{\circ} \mathrm{S}$ it is estimated to be about 17-20 Sv (Rintoul 1991; Zangenberg and Siedler 1998; Ganachaud and Wunsch 2000). Even though the NADW production is overestimated, its outflow at $30^{\circ} \mathrm{S}$ is consistent with the observed value. In the Atlantic basin, the simulated SO outflow across the equator is about $4 \mathrm{~Sv}$, which is close to some observational estimates (McCartney and Curry 1993; Hogg et al. 1999) and is slightly lower than other observations (Ganachaud and Wunsch 2000).

In the Pacific Ocean, the water mass originating from the SO fills most of the basin and the SO outflow is about $10 \mathrm{~Sv}$. This value is within the uncertainty ranges of 
(a) Overturning streamfunction (Global)
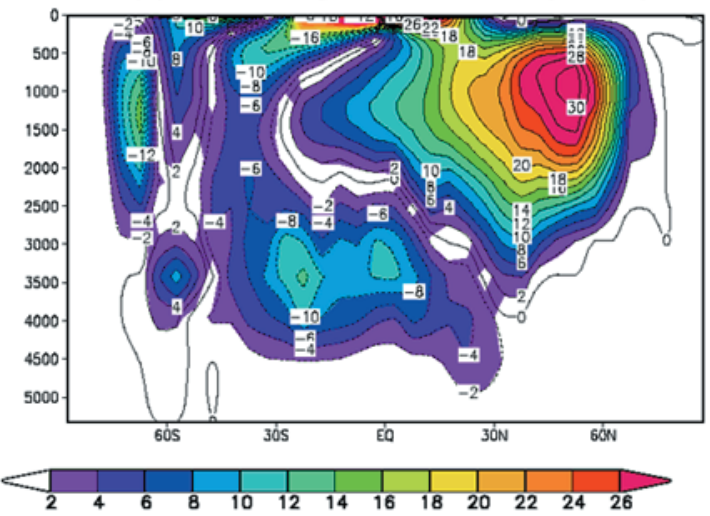

(c) Overturning streamfunction (Pacific)

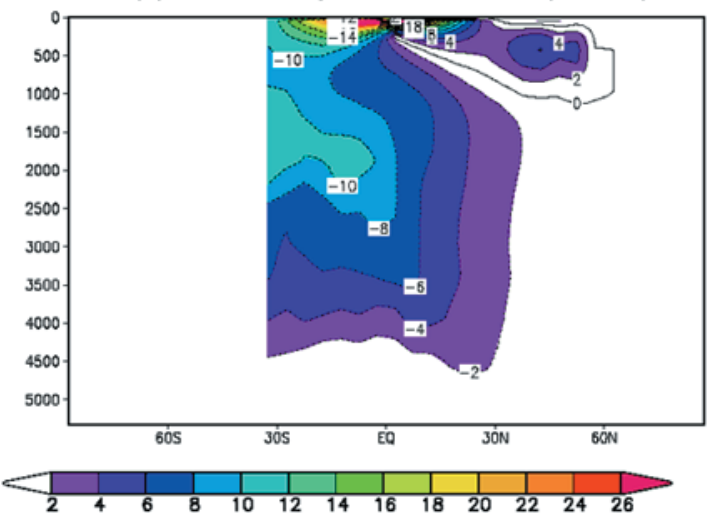

(b) Overturning streamfunction (Atlantic)

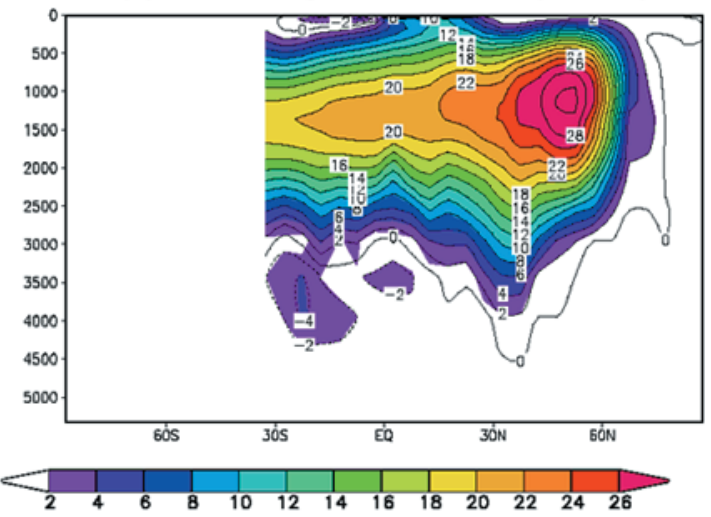

(d) Ocean meridional HF

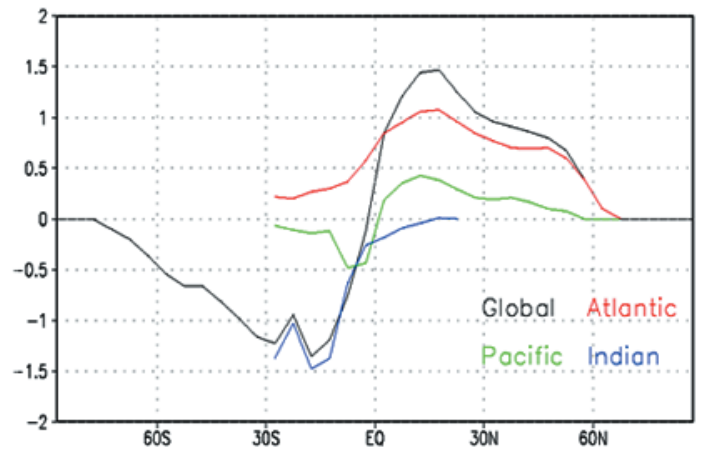

Fig. 4. Vertical distributions of the meridional overturning streamfunction integrated over (a) global, (b) Atlantic, (c) Pacific, and (d) ocean meridional heat fluxes zonally and vertically integrated over the global, Atlantic, Pacific, and Indian Oceans simulated in the REF experiment. Units are $\mathrm{Sv}\left(1 \times 10^{6} \mathrm{~m}^{3} \mathrm{~s}^{-1}\right)$ for streamfunction and PW $\left(1 \times 10^{15}\right.$ watt $)$ for heat fluxes

observations (Ganachaud and Wunsch 2000). In the North Pacific, the positive cell above $1000 \mathrm{~m}$ is associated with the Pacific Intermediate Water (NPIW) production (Fig. 4c), which is widely distributed at depths of 300-800 m (Talley 1991, 1993; Shcherbina et al. 2003). The NPIW production rate is suggested to be about $2 \mathrm{~Sv}$ (Macdonald 1998; Talley 2003), which is lower than the simulated value. In the Indian Ocean, the SO outflow is $12 \mathrm{~Sv}$ (not shown), which is within the uncertainty ranges of observations (Ganachaud and Wunsch 2000).

NADW, AABW, and NPIW production occurs through an oceanic convection in small scattered regions in high latitudes where the ocean water column is marginally stable and stratified. In the observations, the lower part of NADW is produced in the Greenland-Norwegian Sea, while the upper part of NADW is formed in the Labrador Sea of the northern North Atlantic. A large portion of AABW is produced in the Weddell and Ross Seas, and some part is produced off the Adélie Coast (Whitworth et al. 1998). The locations of water mass production are reasonably well reproduced in the distribution of simulated convection (Fig. 14a).

The meridional overturning circulation plays a critical role in oceanic heat transport, which is a critical component of the global climate system. Although observationallybased estimates of heat transport are rather uncertain, the simulated global zonal-mean meridional heat transport of REF (Fig. 4d) appears to agree reasonably well with observed estimates and the general pattern is close to that inferred from NCEP and ECMWF re-analysis (Garnier et al. 2000; Trenberth and Caron 2001). In the observed estimates inferred from NCEP and ECMWF re-analysis, the maximum northward heat transport is slightly over 1.5 PW $\left(\mathrm{PW}=10^{15} \mathrm{~W}\right)$ at around $15^{\circ} \mathrm{N}$, which is comprised of $1 \mathrm{PW}$ from the Atlantic Ocean and $0.5 \mathrm{PW}$ from the Pacific Ocean (Garnier et al. 2000; Trenberth and Caron 
(a) Surface air temperature

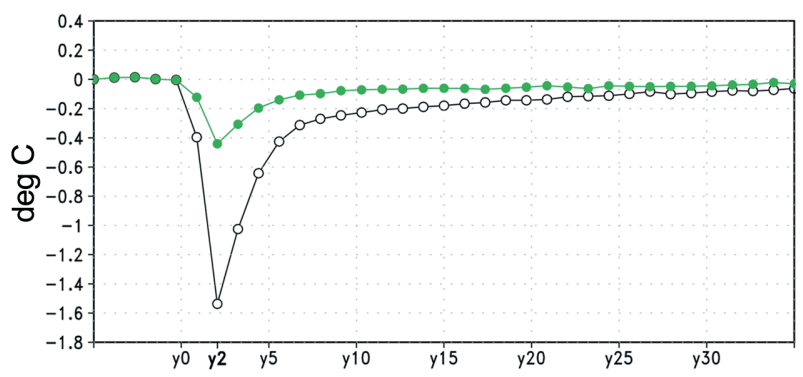

(b) Sea surface temperature

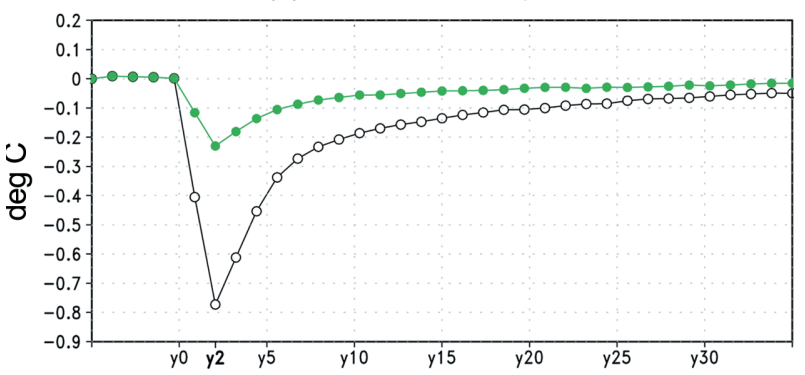

(c) NADW production

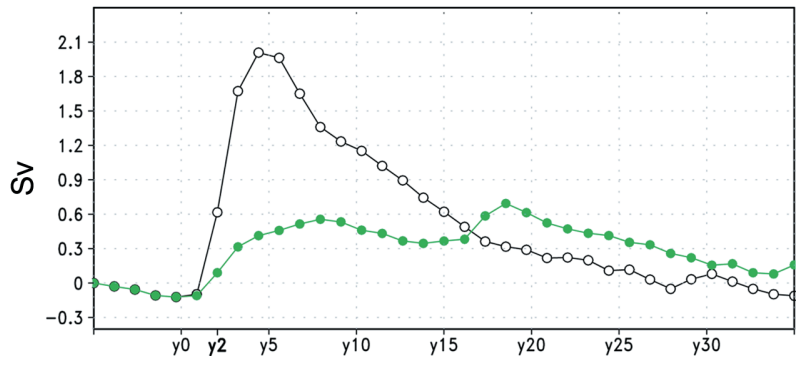

Fig. 5. Time evolution of the global mean (a) surface air temperature (SAT), (b) sea surface temperature (SST), (c) NADW production before and after the Pinatubo (green) and 1259 (black) volcanic eruptions

2001). These estimates are consistent with the simulated meridional heat transport. In the $\mathrm{SH}$, the maximum southward heat transport is about $1.3 \mathrm{PW}$ at about $15^{\circ} \mathrm{S}$, which also agrees reasonably well with observational estimates. However, the southward heat transport in the Indian Ocean appears to be overestimated in comparison to the observations although uncertainties are relatively high.

Overall, the LSG/EBM model captures features of contemporary ocean found in observations in a reasonable manner with such low horizontal and vertical resolutions. In particular, the northward ocean heat transport, which is a critical component in global climate, is reproduced well and gives a reasonable representation of ocean thermohaline properties and circulation.

\section{Response to volcanic eruptions}

The radiative forcing representing the Pinatubo eruption and the 1259 volcanic eruptions resulted in marked changes in ocean properties. Fig. 5 displays the time variation of surface air temperature (SAT), SST, and NADW production rate. As would be expected from the reduction of radiative forcing, the global mean SAT and SST decreased with time and the largest reduction occurred in the following year after the eruption. In the second year after the eruption, SAT decreased by about $0.4^{\circ} \mathrm{C}$ in the Pinatubo event and about $1.6^{\circ} \mathrm{C}$ in the 1259 eruption, while SST decreased by $0.25^{\circ} \mathrm{C}$ and $0.8^{\circ} \mathrm{C}$, respectively. NADW production increased by $2.1 \mathrm{~Sv}$ in the fourth year after the 1259 eruption, which is about $7 \%$ of the total production, whereas in the Pinatubo eruption event, NADW production increased by $0.6 \mathrm{~Sv}$ in the seventh year and the second peak with $0.7 \mathrm{~Sv}$ occurred in the 16 th year. Overall, the volcanic eruptions led to marked surface cooling and increase in NADW production.

\section{Temperature}

The evolution of the zonally averaged annual mean SAT and ocean temperature change in response to the 1259 event from the reference experiment is shown in Fig. 6. We present the results of the 1259 event only because the response of the ocean to the Pinatubo eruption was much less pronounced than that of the 1259 eruption. In response to the 1259 volcanic eruption, a marked surface cooling occurred rapidly in high northern latitudes and less rapidly in southern mid latitudes. The strong cooling in high northern latitudes was mainly due to the change in forcing associated with the land mass over northern Eurasia and North America as shown later. The SAT reduction diminished rapidly with time and after the fifth year the SAT returned to normal. The large interhemispheric asymmetry in the SAT response is a prominent feature of the initial adjustment of the atmosphere to volcanic eruption.

In response to the 1259 eruption, the surface ocean temperature decreased with time (Fig. 6b). The biggest cooling occurred at about $10^{\circ} \mathrm{N}$ from the second year and the cold signature persists until the third year. A cooling signature occurred in the southern low latitude at about $15^{\circ} \mathrm{S}$. At $100 \mathrm{~m}$, the biggest ocean temperature reduction occurred in the third year at about $25^{\circ}$ in both hemispheres. At depths deeper than $200 \mathrm{~m}$, the ocean temperature reduction was substantially less than the upper layers, but the cold signature persists at about $50^{\circ}$ in both hemispheres. At surface, the ocean cooling occurred at low latitudes 
(a) SAT change

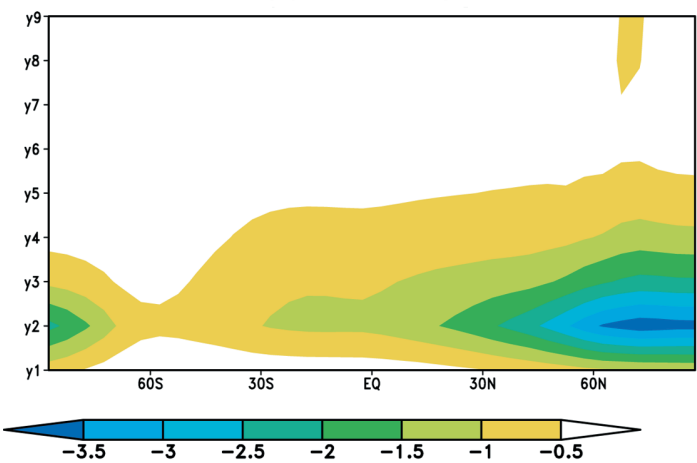

(c) Temp change at $100 \mathrm{~m}$

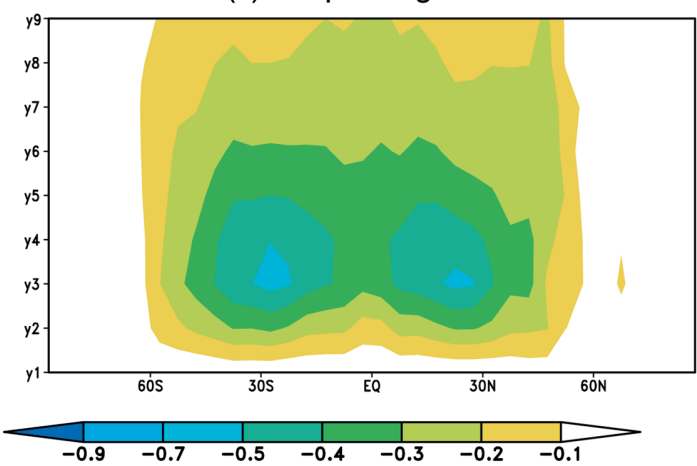

(e) Temp change at $300 \mathrm{~m}$

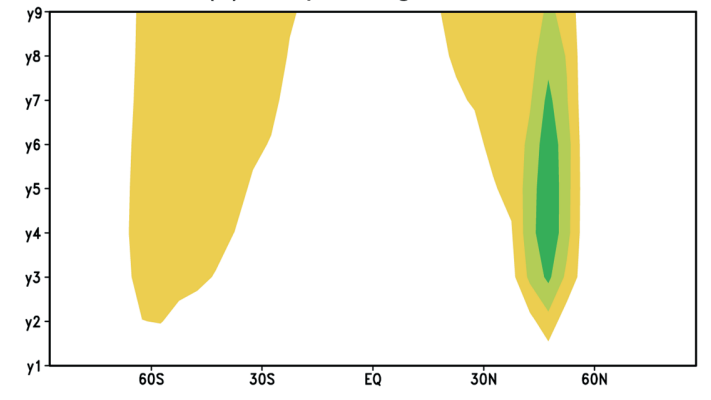

\begin{tabular}{ccccccc}
\hline & $\mid$ & & & & & \\
\hline-0.9 & -0.7 & -0.5 & -0.4 & -0.3 & -0.2 & -0.1
\end{tabular} (b) SST change

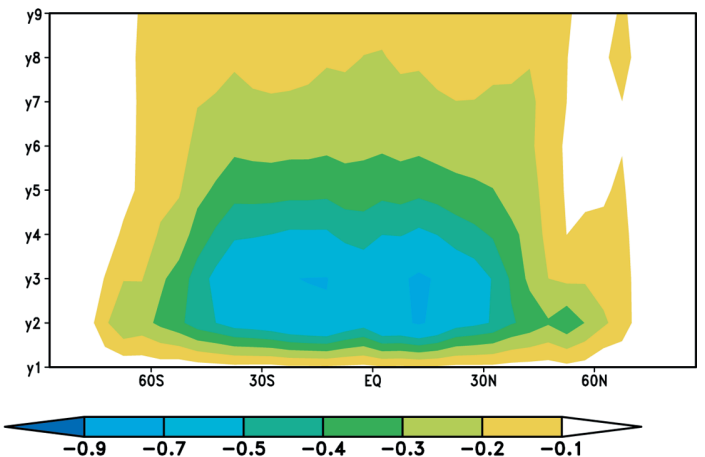

(d) Temp change at $200 \mathrm{~m}$

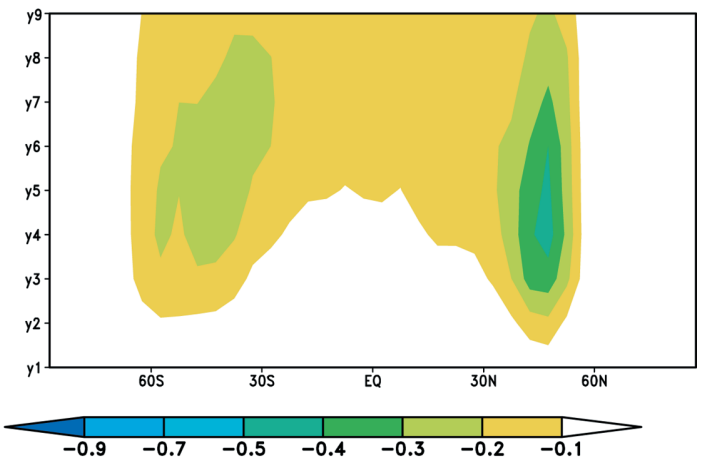

(f) Temp change at $400 \mathrm{~m}$
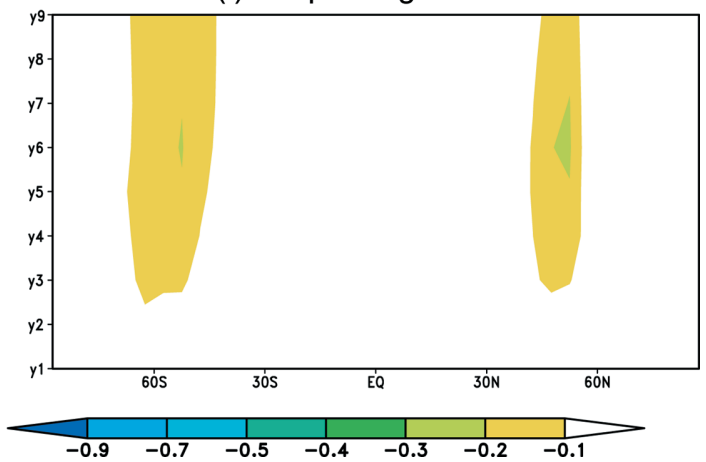

Fig. 6. Time evolution of the change in zonal mean (a) surface air temperature (SAT), (b) sea surface temperature (SST), temperature at (c) $100 \mathrm{~m}$, (d) $200 \mathrm{~m}$, (e) $300 \mathrm{~m}$, and (f) $400 \mathrm{~m}$ between the REF and 1259 experiments

associated with the marked surface cooling of land masses of Asia, America, and Africa, while at deeper layers the cooling signatures were found at higher latitudes, presumably associated with the increase of ocean vertical mixing. Overall, the ocean temperature reduction signature persisted much longer than SAT and occurred more symmetrically than that of SAT with slightly greater cooling in the northern hemisphere than in the southern hemisphere.

Fig. 7 displays the geographic distribution of the annual mean SAT response to the 1259 volcanic eruption. In response to the strong volcanic eruption, a marked reduction in SAT occurred in the second year. The biggest surface cooling by more than $5^{\circ} \mathrm{C}$ occurred over Siberia and the second biggest cooling by more than $3.5^{\circ} \mathrm{C}$ occurred over North America. Relative to land areas, the surface cooling was overall smaller in the ocean, due to a larger heat capacity. In the third year, the surface cooling was still substantial over Siberia and high northern latitudes of land areas. From the fourth year, the surface temperature recovered although the widespread cooling signatures were still present.

Fig. 8 shows the geographic distribution of the ocean 
(a) SAT change (yr1-ref)

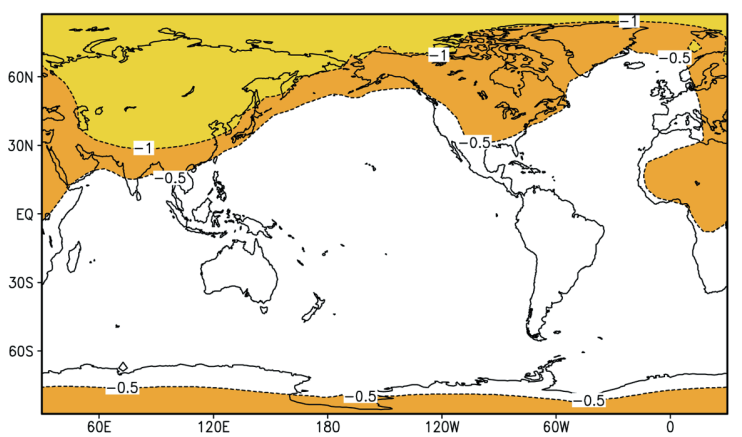

(a) SAT change (yr3-ref)

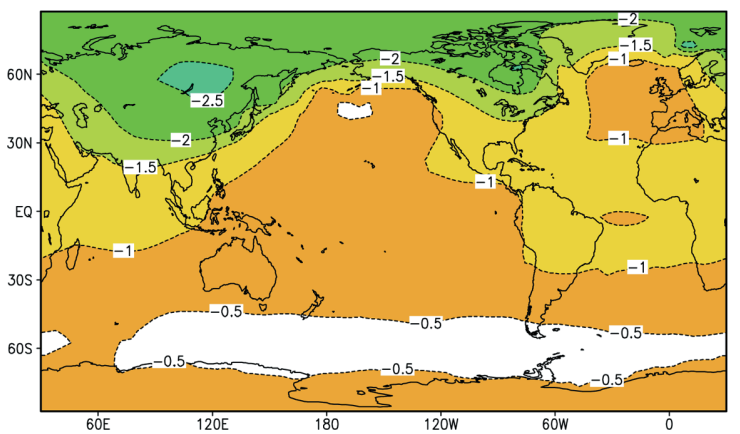

(b) SAT change (yr2-ref)

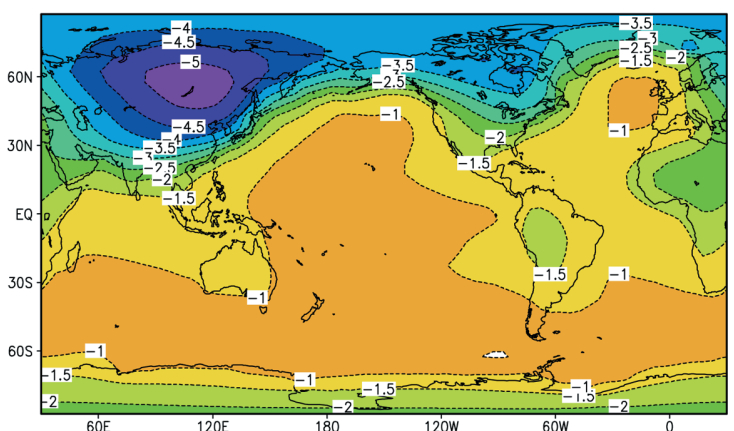

(b) SAT change (yr4-ref)

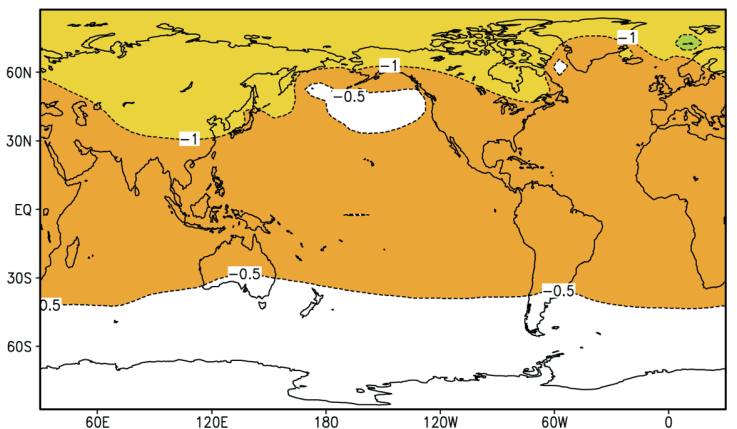

Fig. 7. Geographic distribution of the change in SAT in the (a) first, (b) second, (c) third, and (d) fourth year after the 1259 volcanic eruption

(a) SST change

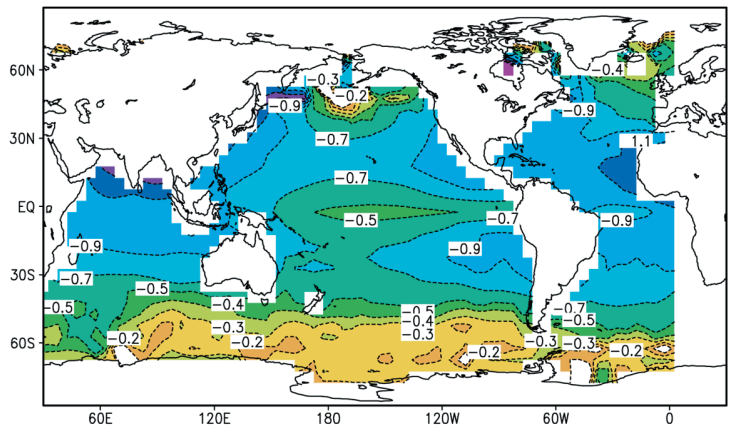

(c) Temp change at $200 \mathrm{~m}$

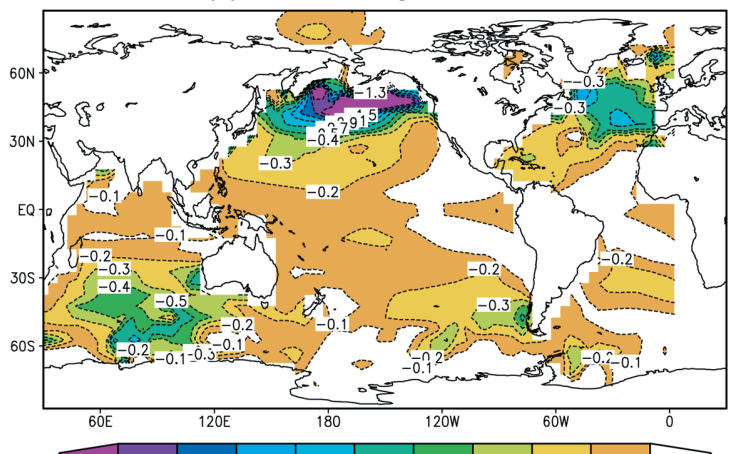

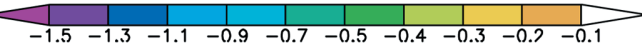

(b) Temp change at $100 \mathrm{~m}$

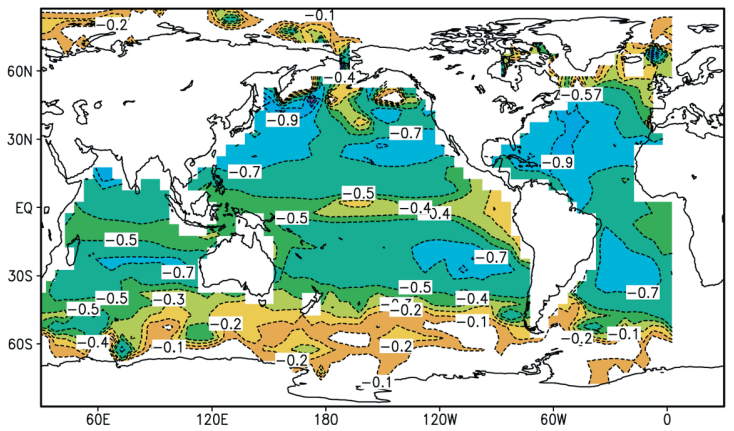

(d) Temp change at $300 \mathrm{~m}$
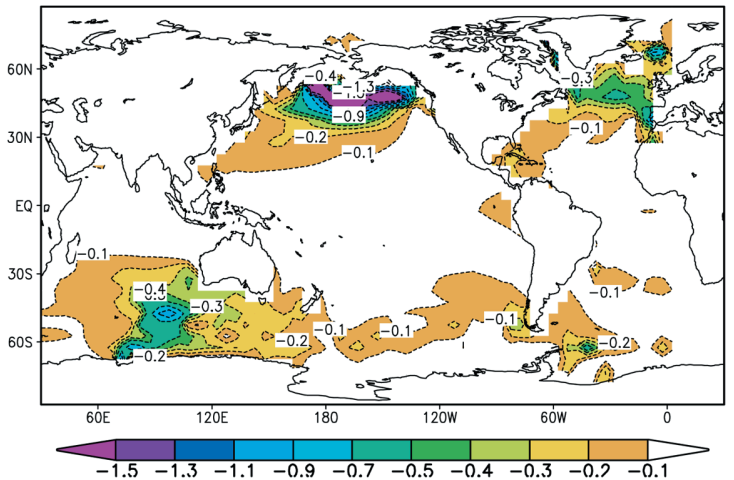

Fig. 8. Geographic distribution of the change in ocean temperature at (a) surface, (b) $100 \mathrm{~m}$, (c) $200 \mathrm{~m}$, and (d) $300 \mathrm{~m}$ 
(a) Atlantic temp change

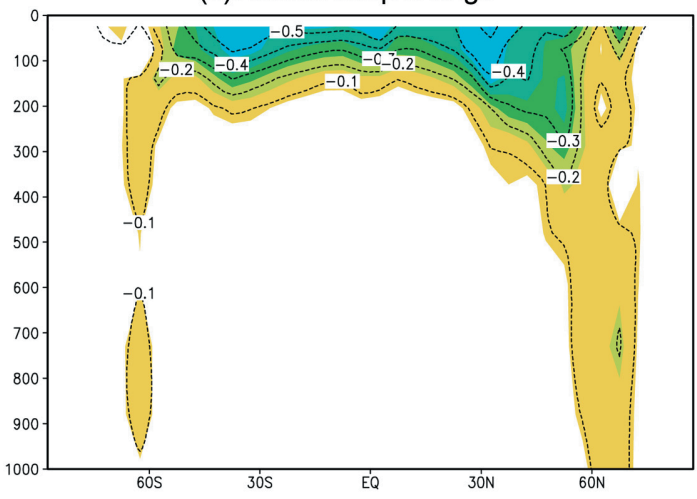

(c) Atlantic salinity change

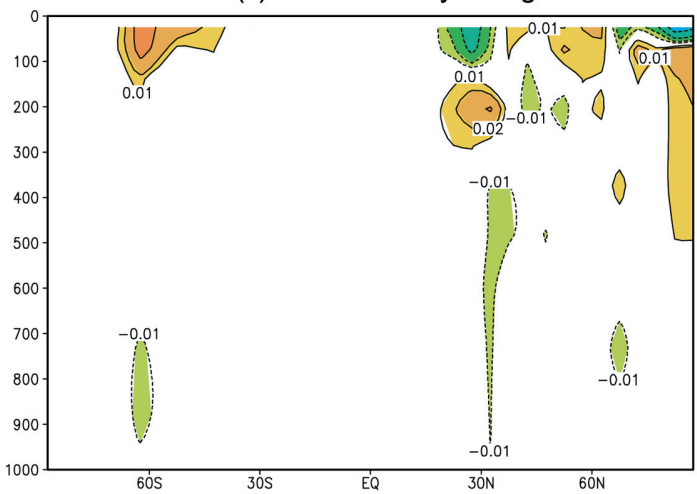

(b) Pacific temp change

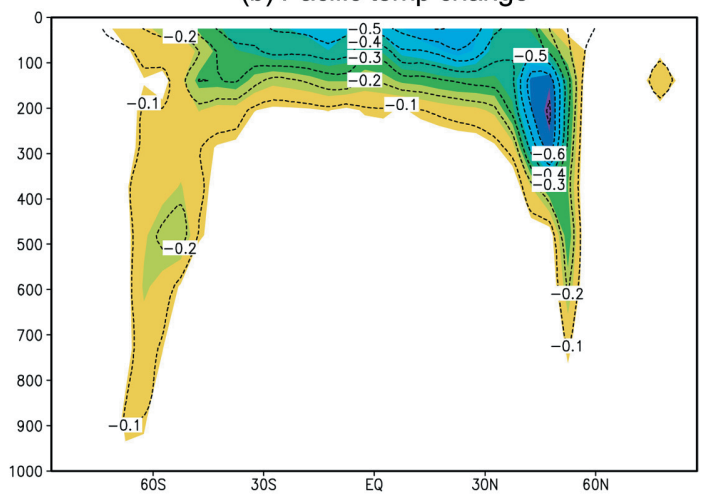

(d) Pacific salinity change

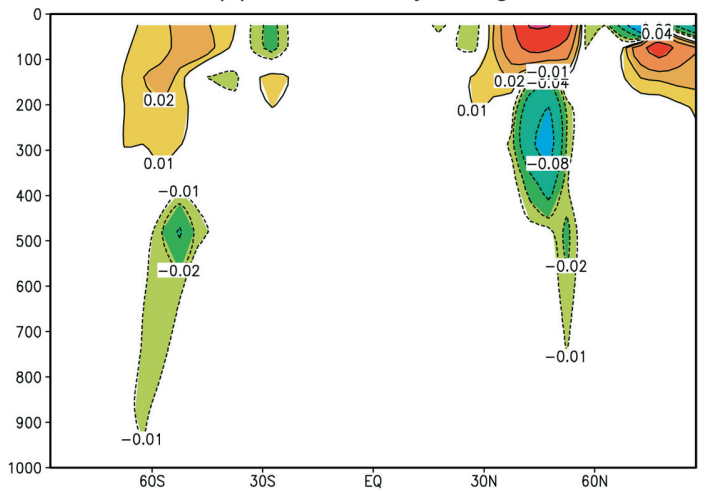

Fig. 9. Vertical distribution of the change in temperature between the REF and 1259 experiments averaged over (a) Atlantic and (b) Pacific Oceans, and the change in salinity averaged over (c) Atlantic and (d) Pacific Oceans

temperature change in the surface, $100 \mathrm{~m}, 200 \mathrm{~m}$, and $300 \mathrm{~m}$. In the ocean surface, the biggest temperature reduction occurred in the northern Indian Ocean and western North Pacific, associated with the marked surface cooling over Eurasia. A marked cooling by more than $0.9^{\circ} \mathrm{C}$ also occurred where the ocean upwells such as the eastern Pacific Ocean and Atlantic Ocean in both hemispheres. In the tropical Pacific and the Southern Ocean, surface ocean cooling was comparatively smaller than other regions because the surface cooling was much larger over ocean regions neighboring land masses in the northern hemisphere than over the open ocean. In the tropical Pacific, the relatively lesser degree of cooling was also associated with the reduction in ocean upwelling as illustrated later. The little SST change in high latitudes was due to the sea ice coverage. At $100 \mathrm{~m}$, the temperature reduction was relatively large in the subtropics in both hemispheres. In the northern North Atlantic and the SO, on the other hand, the temperature reduction was quite small. At $200 \mathrm{~m}$, the biggest ocean temperature reduction occurred in the northern North Pacific and the second largest reduction over the northern North Atlantic. In contrast to the temperature change in the upper layers, at layers deeper than $200 \mathrm{~m}$, the biggest ocean temperature reduction occurred in the northern North Pacific. This difference is to due to the vertical exchange of heat between upper cold water and lower water masses by enhancement of the vertical mixing as shown later.

Fig. 9 displays the annual mean distributions of vertical ocean temperature zonally averaged in the Atlantic and Pacific Oceans. In the Atlantic and Pacific Oceans, the ocean cooling was confined to depths less than $200 \mathrm{~m}$ in low-latitudes to mid-latitudes, but in high latitudes the ocean cooling reached about $1000 \mathrm{~m}$. In the North Atlantic, the ocean cooling reached even deeper levels and in the North Pacific the intense cooling occurred at 200-300 m. Overall, in response to the strong volcanic eruption, the surface air cooled substantially over lands than in the ocean, especially in Eurasia and North America. The marked surface cooling in those areas led to the ocean cooling to depths of several hundred meters and the cold anomaly lasted more than a decade. 


\section{Salinity}

Fig. 10 displays the zonally averaged annual mean evolution of salinity change due to the 1259 volcanic eruption from the reference experiment. In the ocean surface, the salinity markedly decreased in the high northern latitudes and this negative salinity signature persisted for about 10 years. On the other hand, in mid latitudes in both hemispheres, surface salinity increased and this persisted for about 10 years. At $100 \mathrm{~m}$, the salinity increase is found in mid latitudes in both hemispheres and in high northern latitudes of the Arctic. In contrast to the increase in salinity at depths shallower than $100 \mathrm{~m}$, at deeper layers, salinity was slightly reduced in northern hemisphere mid latitudes and this freshening persisted for several years. As illustrated below, the contrasting salinity change between upper and lower layers in mid latitudes and the Arctic was due to the change in ocean convection caused by the volcanic eruption.

Fig. 11 shows the geographic distribution of the annual mean salinity change from the reference case at different depths. At surface, the salinity markedly increased in the northern North Pacific by more than 0.3 psu. In the northern North Atlantic and the SO, surface salinity

(a) Surface salinity change
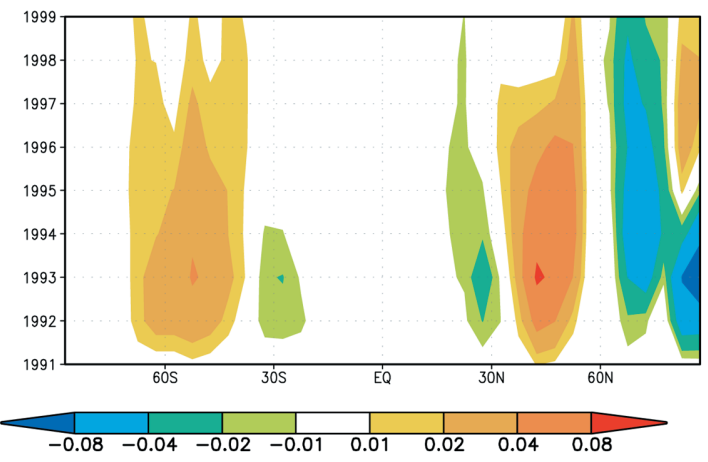

(c) Salinity change at $200 \mathrm{~m}$

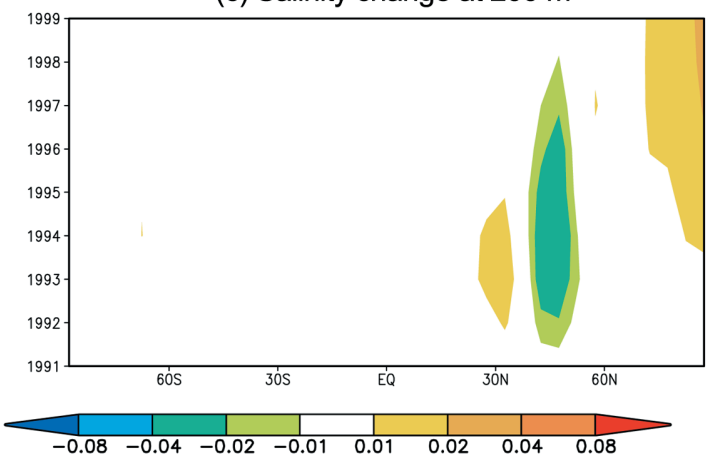

substantially increased as well. In the subtropics and Arctic, on the other hand, the surface salinity decreased in response to the volcanic eruption. At $100 \mathrm{~m}$, the change in salinity was similar to that of surface layer, i.e., the high salinity in the northern North Pacific and the SO was retained. However, in the Arctic, salinity substantially increased at $100 \mathrm{~m}$ layer in contrast to that of the surface layer. At depths deeper than $200 \mathrm{~m}$, a substantial reduction in salinity was found in the northern North Pacific. The contrasting changes in salinity in upper layers shallower than $100 \mathrm{~m}$ and lower layers deeper than $200 \mathrm{~m}$ were also well represented in the vertical distribution of the change in salinity averaged in the Atlantic and Pacific (Fig. 9). In the Arctic, the surface became fresher and subsurface became saltier. On the other hand, in the northern North Pacific, the surface became substantially saltier and vice versa in subsurface layers. In the northern North Atlantic, a similar change in salinity to that of the North Pacific Ocean occurred, but the degree of change was much less. In the SO, upper layers tended to be saltier.

The contrasting changes in salinity in upper layers shallower than $100 \mathrm{~m}$ and lower layers deeper than $200 \mathrm{~m}$

(b) Salinity change at $100 \mathrm{~m}$

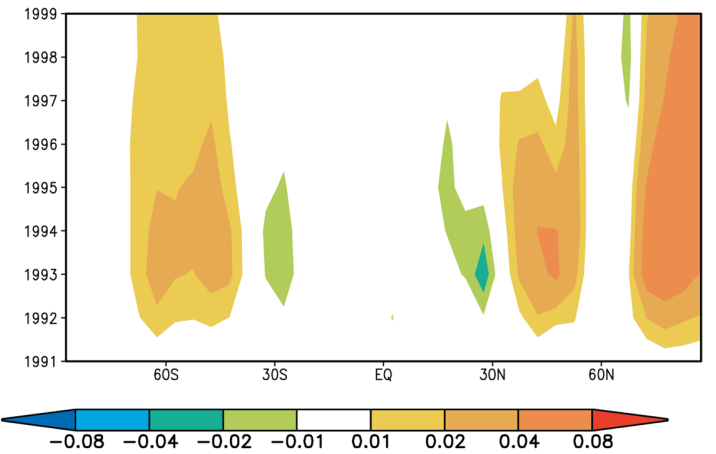

(d) Salinity change at $300 \mathrm{~m}$

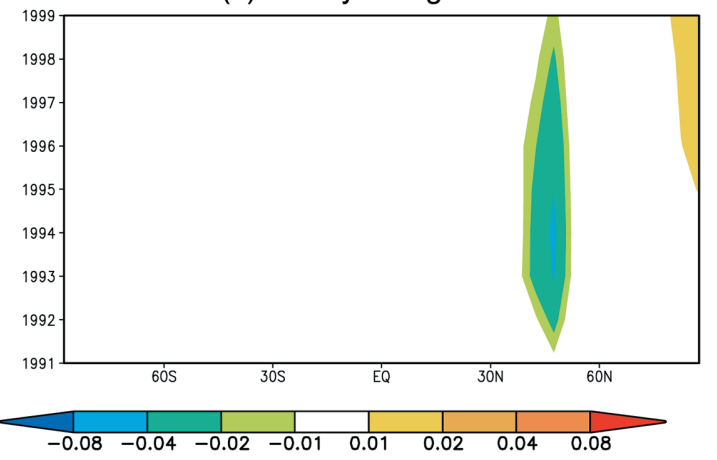

Fig. 10. Time evolution of the zonal mean salinity at (a) surface, (b) $100 \mathrm{~m}$, (d) $200 \mathrm{~m}$, (d) and $300 \mathrm{~m}$ between the REF and 1259 experiments 
(a) Surface salinity change

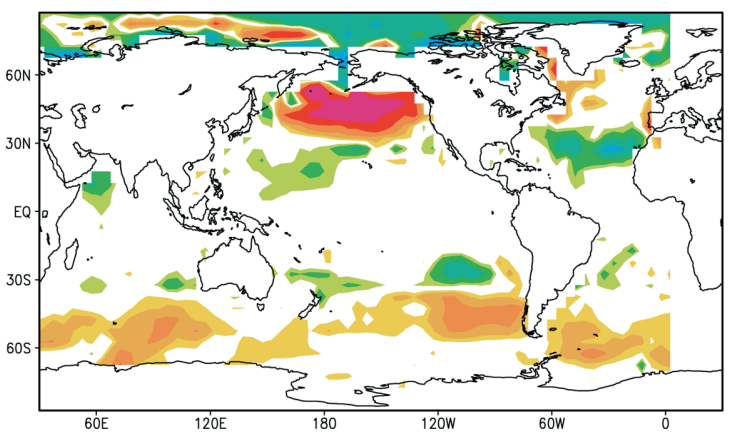

(c) Salinity change at $200 \mathrm{~m}$

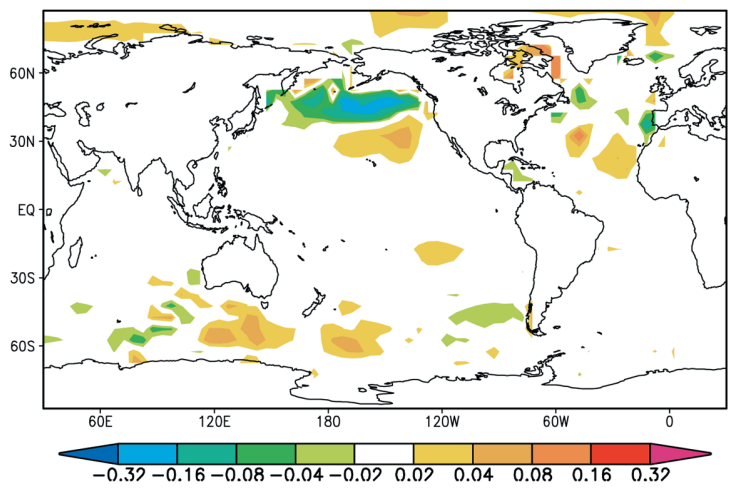

(b) Salinity change at $100 \mathrm{~m}$

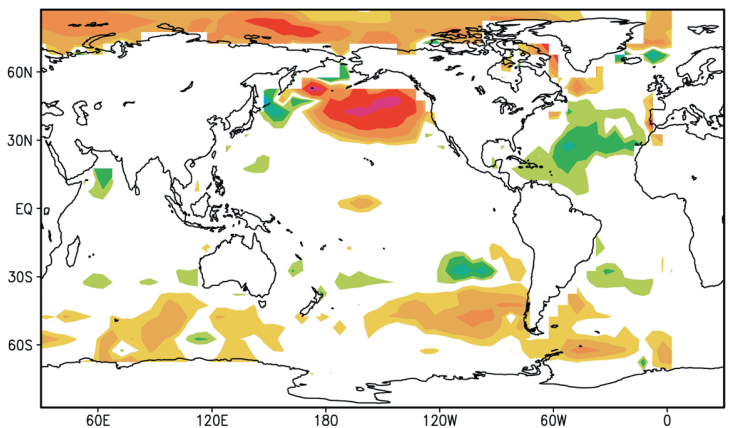

(d) Salinity change at $300 \mathrm{~m}$

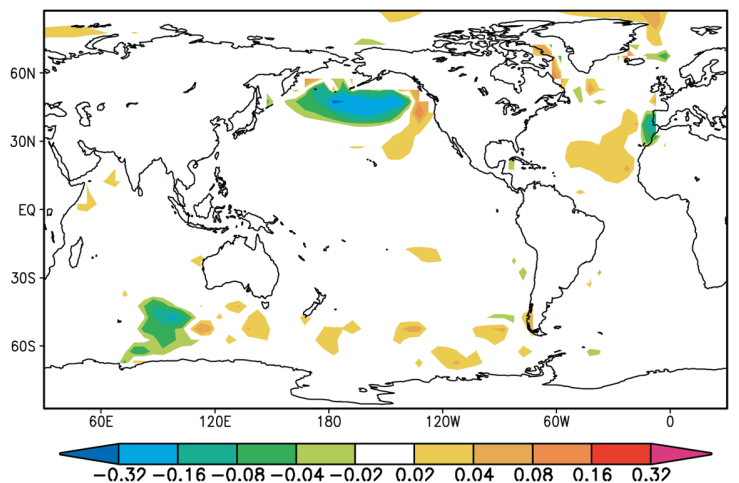

Fig. 11. Geographic distribution of the change in salinity at (a) surface, (b) $100 \mathrm{~m}$, (c) $200 \mathrm{~m}$, and (d) $300 \mathrm{~m}$

are due to the enhanced vertical convection. In the Arctic and northern North Pacific, surface salinity is substantially lower than subsurface by about 2-3 psu in the former and by about 1.5-2 psu in the latter. With the volcanic eruption, the surface of the Arctic freshened and thus oceanic convection became inhibited. The less vigorous vertical mixing then led to an increase in subsurface salinity in the Arctic. In the northern North Pacific, on the other hand, convection increased with the volcanic eruption (see Fig. $14 \mathrm{~b})$. The increase in vertical ocean mixing through more vigorous convection moves fresher surface water down and saltier subsurface water upwards, resulting in the increase and decrease in salinity in the upper and lower layers, respectively. Since the salinity contrast between surface and subsurface layers was much larger in the Pacific than in the Atlantic, the change in the salinity due the change in ocean convection was much larger in the Pacific than the Atlantic.

Overall, in response to the 1259 volcanic eruption, salinity in upper layers increased at latitudes from 40 to $60^{\circ}$ in both hemispheres and decreased in the subtropics at around $30^{\circ}$, but this feature was reversed in lower layers.

\section{Circulation and heat transport}

Fig. 12 shows the geographic distribution of the change in simulated surface and deep ocean (3000 m) currents, sea surface height, and the ocean barotropic streamfunction. Because there was no change in surface wind stress with the volcanic eruption, the change in horizontal ocean circulation was purely due to the change in ocean thermohaline properties. In the change in surface currents, the most pronounced feature was the marked decrease in equatorial currents in the Pacific, which is consistent with the smaller surface cooling shown in Fig. 8a. In the Atlantic Ocean, on the other hand, the equatorial currents were enhanced and surface cooling was larger than in the tropical Pacific (Fig. 8a). The subtropical surface circulation associated with the Kuroshio Current and the Gulf Stream increased, whereas in the southern hemisphere it decreased. The Somali Current in the Arabian Sea, which is northeastward oriented during May to September, was enhanced substantially. In the SO, the surface currents as a part of the ACC slightly increased, especially in the Pacific and the Atlantic sectors.

There was overall little change in the deep ocean 
(a) Surface currents change

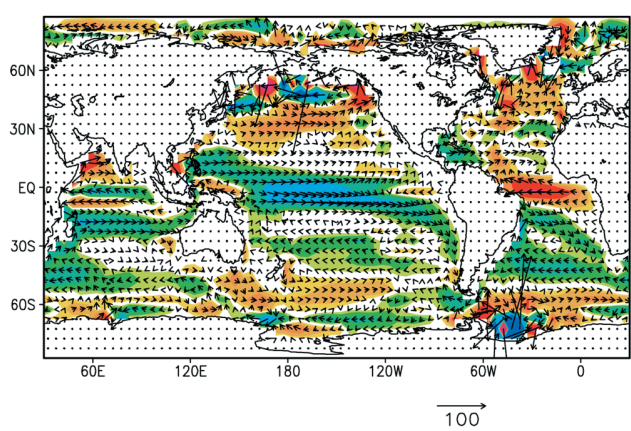

(c) Sea surface height change

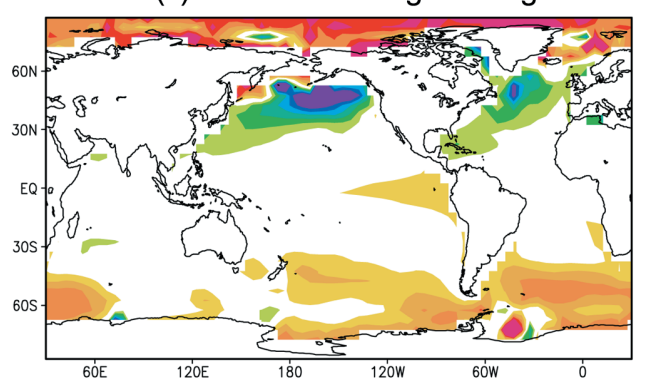

(b) Currents change at $3000 \mathrm{~m}$
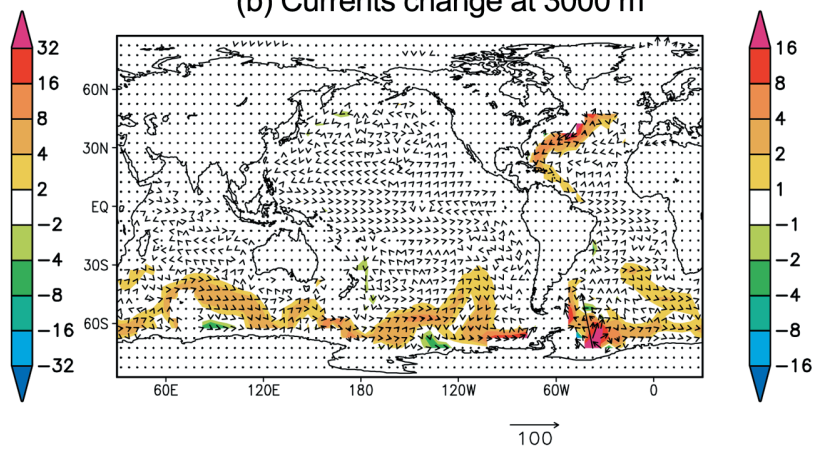

(d) Barotropic streamfunction change

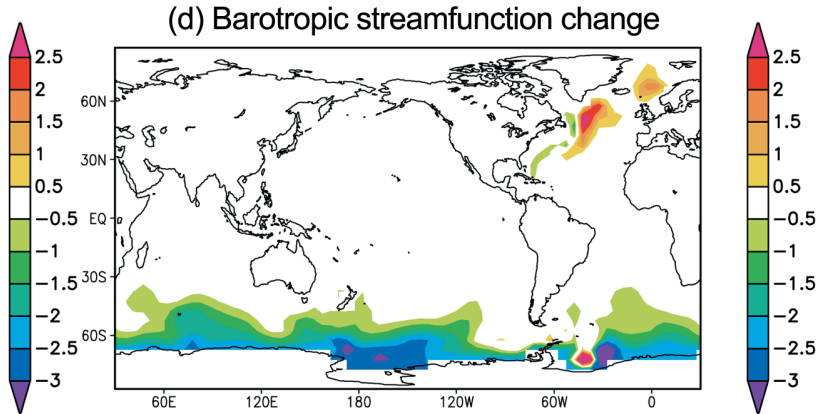

Fig. 12. Geographic distribution of the change in (a) surface currents, (b) currents at $3000 \mathrm{~m}$, (c) sea surface height, and (d) barotropic streamfunction

currents, except for the Atlantic Ocean and the SO (Fig. 12b). In the North Atlantic, the southward deep western boundary currents were enhanced and, in the South Atlantic, the northward deep currents increased. These were associated with the increase in the production and outflows of NADW and AABW as shown later. In the $\mathrm{SO}$, the deep ocean currents composing of the ACC are enhanced.

In response to the volcanic eruption, the sea surface height markedly decreased in the North Pacific (Fig. 8c). A substantial reduction in the surface height also resulted in the northern North Atlantic. These were the places of the marked subsurface cooling at depths deeper than 200 m. In the southern South Pacific and southern South Atlantic, sea surface height increased. These were coincident with relatively less cooled areas. The decrease in sea surface height in the northern North Pacific and North Atlantic relative to low latitudes indicates the weakening of geostrophic currents in the subtropical region because the surface winds stress does not change with volcanic eruption. This was consistent with the increase in the Kuroshio Current and the Gulf Stream in Fig. 12a. In a similar way, the increase in surface height in southern mid latitudes relative to low latitudes weakened subtropical circulation. The change in the barotropic circulation shows the slight weakening of the ACC transport by about $3 \mathrm{~Sv}$ (Fig. 12d). In the northern North Atlantic, the subpolar gyre circulation increased by more than $2 \mathrm{~Sv}$, which is about a $20 \%$ increase, whereas there was a slight reduction in the Gulf Stream transport.

Fig. 13 shows the change in meridional overturning streamfunction. The biggest change caused by the volcanic eruption was NADW production, which increased by about $10 \%$ within 5 years, but its outflow was mostly limited to the North Atlantic. A reduction of NADW production cell is shown in the northern North Atlantic, indicating the southward shift of the production cell. In the southern high latitudes, the AABW production also increased by about $10 \%$. In the North Pacific Ocean, a substantial increase in overturning circulation associated with the NPIW production is visible. In the deep Pacific Ocean, the northward SO outflow is slightly enhanced. There is little change in the meridional overturning circulation in the Indian Ocean.

The increase in NADW production and its outflow is consistent with the increase in the ocean convection in the Norwegian Sea and the Labrador Sea (Fig. 14b). As shown in Fig. 8 and 11, the volcanic eruption led to a reduction in surface temperature and increase in surface salinity in convection regions such as the Norwegian and 
(a) Streamfunction change (Global)
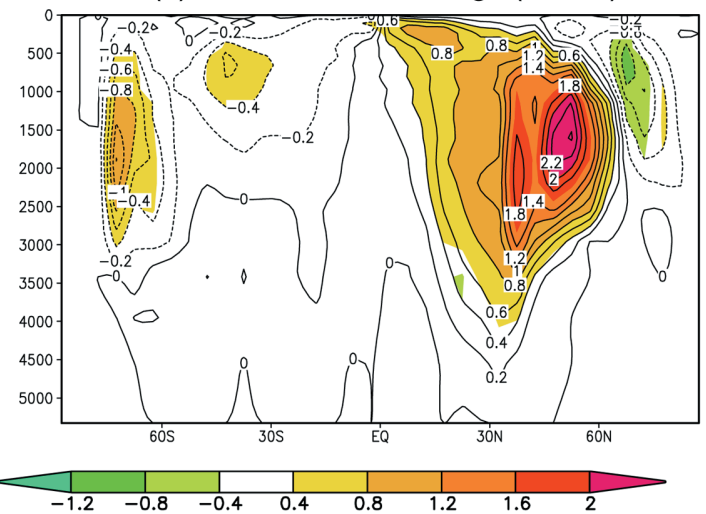

(c) Streamfunction change (Pacific)

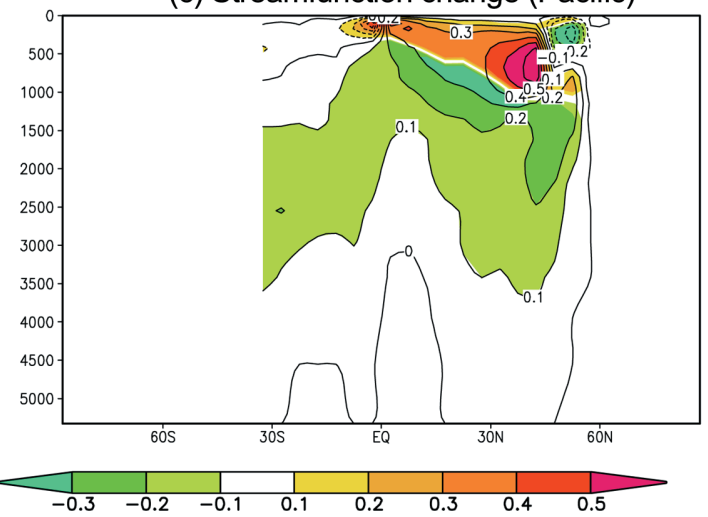

(b) Streamfunction change (Atlantic)

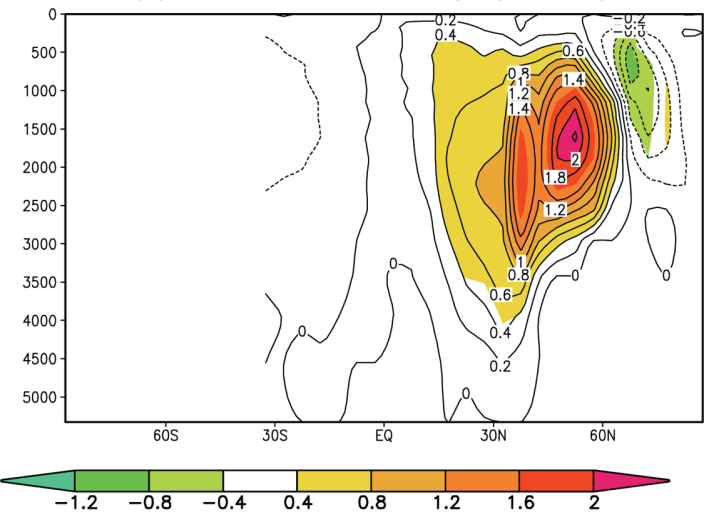

(d) Streamfunction change (Indian)

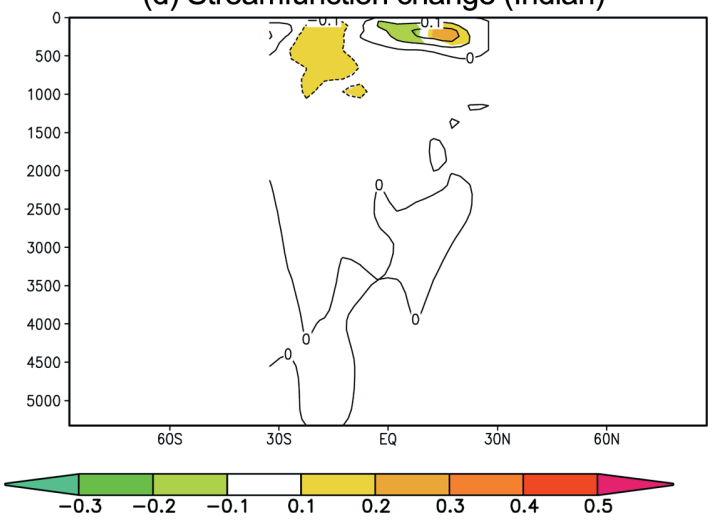

Fig. 13. Vertical distributions of the change in meridional overturning streamfunction (contour) and magnitude (shade) zonallly integrated over (a) global, (b) Atlantic, (c) Pacific, and (d) Indian Oceans

Labrador Seas and the northern Nor Pacific. Since in the northern North Pacific salinity is much lower than that in the northern North Atlantic, the convection was much stronger in the North Atlantic than in the North Pacific. This consequently resulted in an increase in NADW production. A substantial increase in convection also occurred in the Mediterranean Sea. The ocean convection, on the other hand, decreased in the Greenland Sea, consistent with the decrease in the overturning circulation. In the Weddell Sea, Amery Basin, and the Adélie Coast of the SO, and in the western Bering Sea of the North Pacific, the ocean convection increased, inconsistent with the increase in the AABW and NPIW formation.

The change in ocean circulation and thermal property yielded a change in ocean meridional heat flux. Fig. 15 displays the change in meridional heat flux zonally integrated for the global, Atlantic, Pacific, and Indian Oceans averaged for two periods. After the volcanic eruption, during the first 5 years, northward heat flux increased slightly at about $30^{\circ} \mathrm{N}$ and even a slight reduction of the heat flux resulted in the low- latitudes and high-latitudes. The increase and decrease in the northward heat fluxes were due to the change in the meridional heat fluxes in the Atlantic and Pacific Ocean. In the southern hemisphere, the southward heat flux markedly decreased in low latitudes due to the increase of meridional heat flux in the Pacific and Indian Ocean, but it increased in high latitudes associated with the increase in $\mathrm{AABW}$ production. In contrast to the first five years, in the northern hemisphere, the northward heat flux substantially increased, especially in the Atlantic Ocean due to the increase in the North Atlantic Overturning circulation during the second five years. In the southern hemisphere, the southward heat fluxes increased in most latitudes, especially in the SO.

Overall, in response to the volcanic eruption, the surface currents associated with the subtropical gyre circulation increased in the northern hemisphere, but decreased in the southern hemisphere, due to the reduction in sea surface height towards the northern high latitudes and its increase towards southern high latitudes. Meridional overturning 
(a) Convection strength (REF)

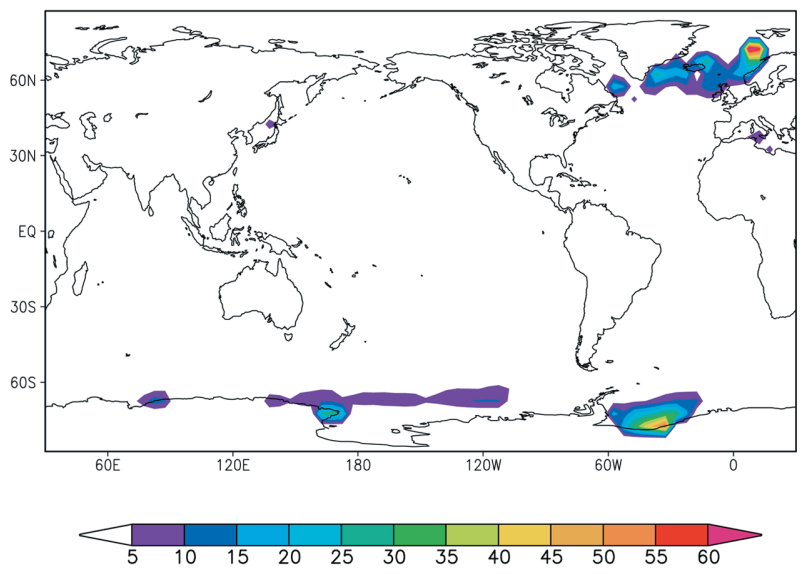

(b) Convection strength change

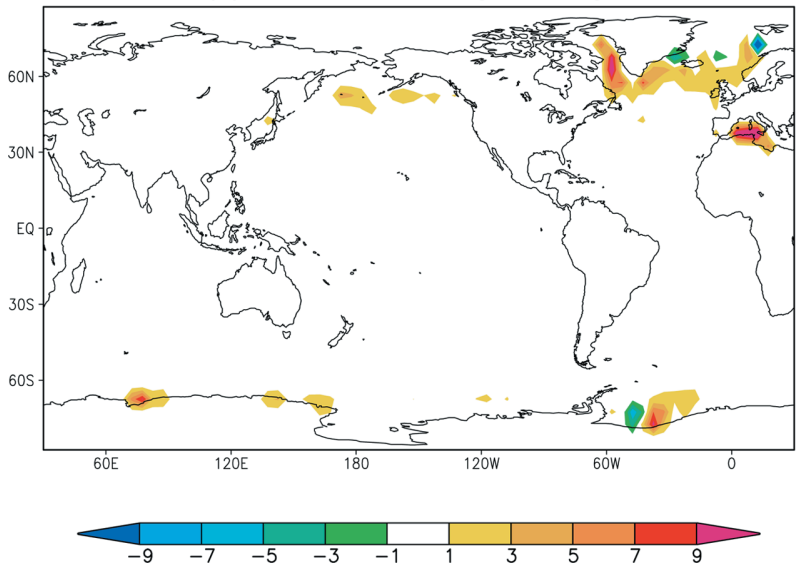

Fig. 14. Geographic distribution of the ocean convection strength simulated in the REF experiment and (b) convection strength change from the $\mathbf{1 2 5 9}$ volcanic experiment. Units are in $\mathrm{mWm}^{-2}$

circulation increased in the North Atlantic and the SO due to the increase in ocean convection. These changes in ocean circulation yielded an increase in northward and southward heat fluxes in the northern and southern hemispheres, respectively.

\section{Comparison to other model results}

There have been several studies conducted to examine the response of the ocean to volcanic eruptions. Previously, Jones et al. (2005) performed a numerical experiment to simulate climate response to a volcanic super-eruption assuming that it was about 100 times larger than the 1991 Pinatubo eruption and they obtained a substantial reduction in global-mean surface temperature by about $10.7^{\circ} \mathrm{C}$ about 15 months after the simulated eruption. Since our study applied a radiative forcing about 7 times the 1991 (a) MHF Change (yr1-yr5)

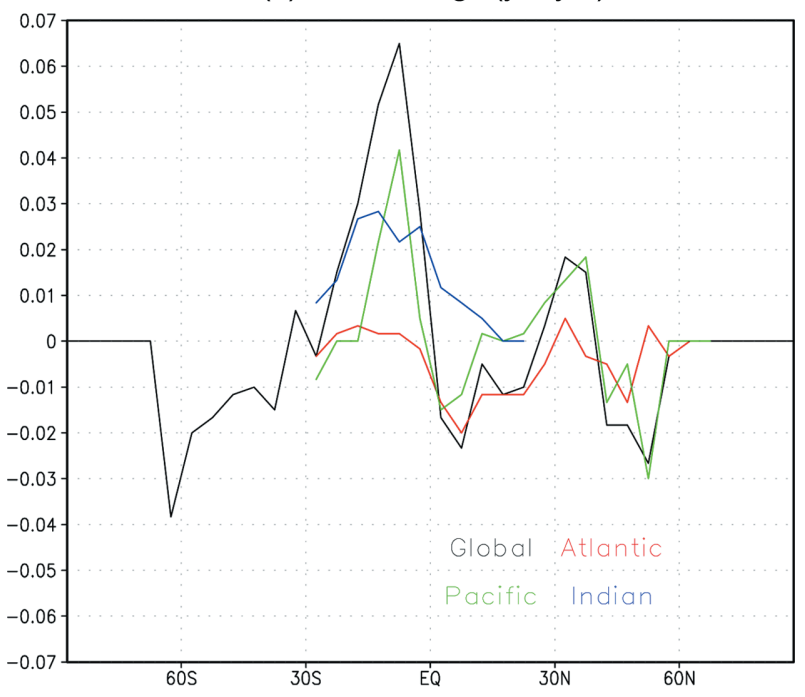

(b) MHF Change (yr6-yr10)

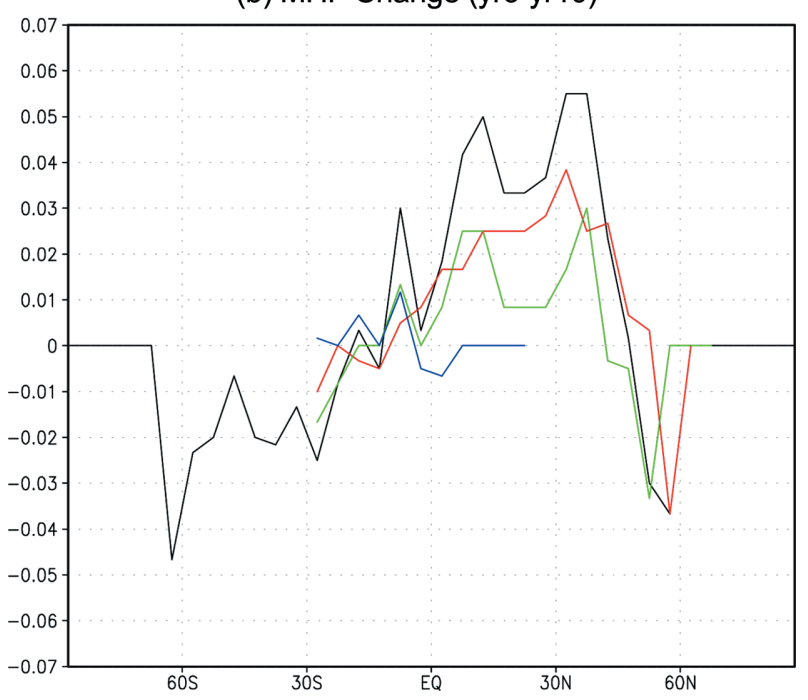

Fig. 15. The change in ocean meridional heat fluxes zonally and vertically integrated over the global, Atlantic, Pacific, and Indian Oceans averaged (a) from the first to 5th year and (b) from the 6th to 10th year. Units are in PW

Pinatubo eruption in 1259 experiment, we expected about a $1.3^{\circ} \mathrm{C}$ cooling compared with the model of Jones et al. (2005) and this degree of cooling is comparable with the response in our model, shown in Fig. 5, where there is an approximate $1.5^{\circ} \mathrm{C}$ cooling. In terms of surface cooling pattern, Jones et al. (2005) obtained the largest cooling over north-eastern America and European Arctic and eastern Siberia, whereas in our model the biggest response appears over central Siberia. This difference seems to be due to the missing feedback related to atmospheric 
circulation and cloud etc. in our model. They obtained a substantially increased overturning circulation in the north Atlantic basin from $15 \mathrm{~Sv}$ at present to $40 \mathrm{~Sv}$ in the simulated super volcanic eruption. The increased response of the Atlantic overturning circulation associated with NADW production is consistent with what we obtained in our study, even though quantitatively it is difficult to compare.

By analysing a series of ocean-atmosphere GCM experiments recently performed by the climate modelling community, Gleckler et al. (2006) investigated the effect of volcanic eruptions on oceanic heat content and penetration of ocean cooling with time. In response to the series of volcanic eruptions that occurred before industrialization, ocean heat content decreased substantially and the low heat content persisted for a long time as a result of recurring volcanic eruptions. Church et al. (2005) investigated the decadal-scale impact of volcanic eruptions on sea level and ocean heat content using the Parallel Climate Model (PCM). They found that in response to the Pinatubo eruption the ocean heat content decreased by $3 \times 10^{22} \mathrm{~J}$ and sea level dropped by $5 \mathrm{~mm}$. The reduction in ocean heat content and the long-lasting cooling anomaly obtained in these studies are consistent with the scenario obtained from model where the cooling signature in subsurface ocean lasts longer than a decade.

Using the GFDL CM2.1 coupled model, Stenchikov et al. (2009) obtained volcanic signals in the ocean in response to the Tambora and Pinatubo eruptions. In the Tambora and Pinatubo experiments, global-mean surface temperatures decreased by $1.2^{\circ} \mathrm{C}$ and $0.4^{\circ} \mathrm{C}$, respectively. The global-mean surface cooling by $0.4^{\circ} \mathrm{C}$ in response to the Pinatubo eruption obtained by Stenchikov et al. (2009) is similar to what we obtained in this study shown in Figure 5. In terms of temperature signals in the ocean, the cold anomaly that penetrated in high northern and southern hemispheres (as in our study) and at depths deeper than $1000 \mathrm{~m}$ reveals the cold anomaly to be about $0.005^{\circ} \mathrm{C}$, which is comparable to our experiment. They obtained an increase in meridional overturning circulation in response to Pinatubo volcanic forcing by $1.8 \mathrm{~Sv}$ in the Atlantic basin after about 7 years. This increase is about three times larger than in our experiment ( $0.6 \mathrm{~Sv}$ increase), but what caused this difference is not immediately clear.

Mignot et al. (2011) examined the response of the Atlantic meridional overturning circulation (AMOC) using the IPSL coupled model with the volcanic forcing for the past millennium and they obtained a weak enhancement of the AMOC, but this anomaly did not persist for more than a few years due to the reduced convection in high northern latitudes under the effect of anomalous sea ice extension. The enhancement of the $\mathrm{AMOC}$ in response to volcanic eruptions is also found in other numerical experiments such as Ottera et al. (2010), Ortega et al. (2011), and Zanchettin et al. (2012) and these previous model results are overall consistent with our results, even though the response of the ocean meridional streamfunction to the volcanic eruptions varies from model to model due to the different thermohaline responses in convection regions and different convective adjustment schemes.

Overall, previous model results suggest that marked surface cooling occurs after a couple of years of volcanic eruptions by several tenths of degrees (about $0.3 \sim 0.5^{\circ} \mathrm{C}$ ) and the surface cooling anomaly penetrated to the ocean subsurface, where the cold anomaly persists for more than a decade. Almost all models show an increase in the Atlantic meridional overturning circulation associated with the increase in convection in the northern North Atlantic. These previous model results are broadly consistent with what we found in this study.

\section{Summary and Conclusion}

The response of the ocean to volcanic eruptions was investigated using the LSG ocean model equipped with an energy balance model (EBM). In the LSG/EBM model, the radiative forcing reduction by about $3 \mathrm{~W} \mathrm{~m}^{-2}$ due to the Pinatubo eruption and by about $21 \mathrm{~W} \mathrm{~m}^{-2}$ due to the 1259 eruption, which is the biggest volcanic eruption over the past millennium, were implemented to investigate the response of ocean thermohaline properties and circulation and associated meridional ocean heat fluxes.

With the contemporary forcing, the model reproduced ocean temperatures slightly warmer in all ocean basins compared with the observation. The simulated salinity was greater than the observation in the North Atlantic, but fresher in other oceans. The AAIW is less distinct in the simulation than the observation, whereas the NPIW is well reproduced. The surface and deep ocean currents, sea surface topography, and ocean barotropic ocean circulation are reproduced reasonably well. NADW production is substantially overestimated, but its outflow at $30^{\circ} \mathrm{S}$ is consistent with the observed estimates. AABW production and its outflow in all ocean basins are also consistent with the observed estimates. The simulated ocean circulation and thermal properties reproduce the meridional ocean heat flux reasonably well. 
With volcanic eruptions, the surface air temperature (SAT) and sea surface temperature (SST) markedly decreases in the year following the eruption. In response to the Pinatubo and 1259 eruptions, the annual and global mean SAT decreased by $0.4^{\circ} \mathrm{C}$ and $1.6^{\circ} \mathrm{C}$, while the SST decreased by $0.25^{\circ} \mathrm{C}$ and $0.8^{\circ} \mathrm{C}$, respectively. The zonally averaged SAT reduction revealed inter-hemispheric asymmetry with larger cooling in northern high latitudes and less cooling in the southern hemisphere, associated with the much larger land mass distribution in the northern hemisphere. In the ocean, the surface temperature reduction occurred more symmetrically with slightly larger cooling in the northern hemisphere. In the northern hemisphere, the largest SAT reductions occurred around Siberia and second largest reduction was in North America, while in the ocean the largest SST reduction occurred in the northern Indian Ocean and eastern Atlantic Ocean. At depths below $200 \mathrm{~m}$, the temperature markedly decreased in the northern North Pacific and this subsurface cooling reached depths of about $700 \mathrm{~m}$.

The sea surface salinity substantially decreased in most of the Arctic Ocean by more than $0.04 \mathrm{psu}$, but surface salinity markedly increased in the northern North Pacific and slightly in the northern North Atlantic and the SO. Sea surface salinity decreased in mid latitudes. At $100 \mathrm{~m}$, salinity increased in the Arctic Ocean in contrast to that of the surface, and the marked salinity increase was also found in the northern North Pacific and the SO. However, at depths below $200 \mathrm{~m}$ salinity substantially decreased in the northern North Pacific, due to the vertical exchange of water masses. A similar feature was found in the SO where surface layers shallower than $300 \mathrm{~m}$ became saltier while depths deeper than $400 \mathrm{~m}$ became fresher until $900 \mathrm{~m}$.

The equatorial currents weakened in the Pacific Ocean, but became stronger in the Atlantic Ocean. The subtropical gyre circulation increased in the northern hemisphere, but decreased in the southern hemisphere due to the fall and rise of sea surface in the northern and southern high latitudes, respectively. The reduction in SST and increase in SSS increased the convection in the northern North Atlantic, around Antarctica, and in the northern North Pacific that led to an increase in NADW, AABW, and NPIW formation and their meridional overturning circulations. The increase in overturning circulation pushed more heat to high latitudes in both hemispheres.

In conclusion, volcanic eruptions perturb ocean temperature and salinity, which consequently modifies ocean circulation and, eventually, meridional heat fluxes. The perturbed signature persists for more than a decade in the ocean in contrast to the atmosphere. This result confirms the role of volcanic eruption in illustrating the decadalscale variability recorded in paleoclimate proxy data for the past millenium, which have been a long-term puzzle due to the short e-folding time.

\section{Acknowledgements}

This study was inspired by professor Thomas J. Crowley, retired from the University of Edinburgh. Professor Arne Winguth at the University of Texas Arlington is especially appreciated for providing the numerical model. This study was mainly supported by the "Reconstruction and Observation of Components for the Southern Annular Mode to Investigate the Cause of Polar Climate Change (PE12010)" and in part by "Understanding of the Teleconnection between Polar and Mid-latitudes and Improvement of Seasonal Forecast by Physical Parameterization over Polar Regions (PN12010)" of Korea Polar Research Institute.

\section{References}

Arakawa A, Lamb VR (1977) Computational design of the basic dynamical process of the UCLA general circulation model. Methods in Computational Physics 17, Academic Press, pp 173-265

Briffa KR (2000) Annual climate variability in the Holocene: interpreting the message of ancient trees. Quaternary Sci Rev 19:87-105

Briffa KR, Jones PD, Schweingruber FH, Osborn TJ (1998) Influence of volcanic eruptions on northern hemi- sphere summer temperatures over the last 600 years. Nature 393:450-455

Carmack EC (1977) Water characteristics of the Southern Ocean south of Polar Front. In: M Engel (ed) Voyage of Discovery. Deep-Sea Res 24:15-41

Church JA, White NJ, Arblaster JM (2005) Significant decadal-scale impact of volcanic eruptions on sea level and ocean heat content. Nature 438:74-77

Crowley TJ, Lowery TS (2000) How warm was the Medieval Warm Period? Ambio 29:51-54

Crowley TJ (2000) Causes of climate change over the past 1000 years. Science 289:270-277

Fieux M, Andrié C, Delecluse P, Ilahude AG, Kartavtseff A, Mantisi F, Molcard R, Swallow JC (1994) Measurements within the Pacific-Indian Oceans throughflow region. Deep-Sea Res 41(7):1091-1130

Frölicher TL, Joos F, Raible CC (2011) Sensitivity of 
atmospheric $\mathrm{CO}_{2}$ and climate to explosive volcanic eruptions. Biogeosciences 8:2317-2339

Ganachaud A, Wunsch C (2000) Improved estimates of global ocean circulation, heat transport and mixing from hydrographic data. Nature 408:453-457

Garnier E, Barnier B, Siefridt L, Béranger K (2000) Investigating the 15 years air-sea flux climatology from the ECMWF re-analysis project as a surface boundary condition for ocean models. Int J Climatol 20:1653-1673

Gleckler PJ, AchutaRao K, Gregory JM, Santer BD, Taylor KE (2006) Krakatoa lives: The effect of volcanic eruptions on ocean heat content and thermal expansion. Geophys Res Lett 33:L17702. doi:10.1029/2006GL026771

Gordon AL (1986) Interocean exchange of thermocline water. J Gephys Res 91(C4):5037-5046

Hellerman S, Rosenstein M (1983) Normal monthly wind stress data over the world ocean with error estimates. J Phys Oceanogr 13:1093-1104

Hogg NG, Siedler G, Zenk W (1999) Circulation and variability at the southern boundary of the Brazil Basin. J Phys Oceanogr 29:145-157

IPCC (2007) Climate Change (2007) The Physical Science Basis. Contribution of working group 1 to the fourth assessment report of the intergovernmental panel on climate change. Cambridge University Press, Cambridge

Jones GS, Gregory JM, Stott PA, Tett SF, Thorpe RB (2005) An AOGCM simulation of the climate response to a volcanic super-eruption. Climate Dyn 25:725-738

Kirchner I, Stechnikov GL, Graf H-F, Robock A, Antuna JC (1999) Climate model simulation of winter warming and summer cooling following the 1991 Mount Pinatubo volcanic eruption. J Geophys Res 104:19039-19055

Levitus S (1982) Climatological Atlas of the World Ocean. NOAA Prof. Paper No. 13, US Government Printing Office, Washington DC, 17 fiches, $173 \mathrm{p}$

Levitus S, Boyer TP (1994) World ocean atlas 1994 Vol. 4: temperature. NOAA Atlas NESIDIS 4, US Department of Commerce, $117 \mathrm{p}$

Levitus S, Burgett R, Boyer TP (1994) World ocean atlas 1994 Vol. 3: salinity. NOAA Atlas NESIDIS 3, US Department of Commerce, $99 \mathrm{p}$

Lukas R, Yamagata T, McCreary JP (1996) Pacific lowlatitude western boundary currents and Indonesian throughflow. J Geophys Res 101:12,209-12,216

Macdonald AM (1998) The global ocean circulation: a hydrographic estimate and regional analysis. Prog Oceanogr 41:281-382

Macdonald A, Wunsch MC (1996) An estimate of global ocean circulation and heat fluxes. Nature 382:436-439
Maier-Reimer E, Mikolajewicz U, Hasselmann K (1993) Mean circulation of the Hamburg LSG OGCM and its sensitivity to the thermohaline surface forcing. J Phys Oceanogr 23:731-757

Mann ME, Bradley RS, Hughes MK (1998) Global-scale temperature patterns and climate forcing over the past six centuries. Nature 392:779-787

Mann ME, Bradley RS, Hughes MK (1999) Northern hemisphere temperatures during the past millennium: inferences, uncertainties, and limitations. Geophys Res Lett 26:759-762

Mann ME, Zhang Z, Rutherford S, Bradley RS, Hughes MK, Shindell D, Ammann C, Faluvegi G, Ni F (2009) Global signatures and dynamical origins of the little ice age and medieval climate anomaly. Science 326:12561260

Maximenko N, Niiler P, Rio M-H, Melnichenko O, Centurioni L, Chambers D, Zlotnicki V, Galperin B (2009) Mean dynamic topography of the ocean derived from satellite and drifting buoy data using three different techniques. J Atmos Ocean Tech 26:1910-1919. doi:10.1175/ 2009JTECHO672.1

McCartney MS, Curry R (1993) Transequatorial flow of Antarctic Bottom Water in the western Atlantic Ocean: Abyssal geostrophy at the equator. J Phys Oceanogr 23:1264-1276

Mignot J, Khodri M, Frankignoul C, Servonnat J (2011) Volcanic impact on the Atlantic Ocean over the last millennium. Clim Past 7:1439-1455

Niiler PP, Maximenko NA, McWilliams JC (2003) Dynamically balanced absolute sea level of the global ocean derived from near-surface velocity observations. Geophys Res Lett 30(22):2164. doi:10.1029/2003GL018628

North GR, Mengel JG, Short DA (1983) Simple energy balance model resolving the seasons and the continents: Application to the astronomical theory of the Ice Ages. J Geophys Res 88:6576-6586

Ortega P, Hawkins E, Sutton R (2011) Processes governing the predictability of the Atlantic meridional overturning circulation in a coupled GCM. Clim Dyn 37:1771-1782. doi:10.1007/s00382-011-1025-1

Orsi AH, Johnson GC, Bullister JL (1999) Circulation, mixing, and production of Antarctic Bottom Water. Prog Oceanogr 43:55-109

Ottera OH, Bentsen M, Drange H, Suo L (2010) External forcing as a metronome for Atlantic multidecadal variability. Nat Geosci 3:688-694

Porter SC (1986) Pattern and forcing of Northern Hemisphere glacier variations during the last millennium. Quaternary 
Res 26:27-48

Read JF, Pollard RT (1993) Structure and transport of the Antarctic circumpolar current and Agulhas return current at $40^{\circ}$ E. J Geophys Res 98:12281-12295

Rintoul SR (1991) South Atlantic interbasin exchange. J Geophys Res 96(C2):2675-2692

Robock A (2000) Volcanic eruptions and climate. Rev Geophys 38(2): 191-219

Sato M, Hansen JE, McCormick MP, Pollack JB (1993) Stratospheric aerosol optical depths, 1850-1990. J Geophys Res 98(D12):22987-22994

Shcherbina AY, Talley LD, Rudnick DL (2003) Direct observations of North Pacific ventilation: Brine rejection in the Okhotsk Sea. Science 302:1952-1955

Shindell DT, Schmidt GA, Mann ME, Faluvegi G (2004) Dynamic winter climate response to large tropical volcanic eruptions since 1600. J Geophys Res 109(D05104). doi:10.1029/2003JD004151

Stenchikov G, Robock A, Ramaswamy V, Schwarzkopf MD, Hamilton K, Ramachandran S (2002) Arctic Oscillation response to the 1991 Mount Pinatubo eruption: Effects of volcanic aerosols and ozone depletion. J Geophys Res 107(D24):4803. doi:10.1029/2002JD002090

Stenchikov G, Kirchner I, Robock A, Graf H-F, Antuna JC, Grainger RG, Lambert A, Thomason L (1998) Radiative forcing from the 1991 Mount Pinatubo volcanic eruption. J Geophys Res 103:13837-13857

Stenchikov G, Hamilton K, Robock A, Ramaswamy V, Schwarzkopf MD (2004) Arctic Oscillation response to the 1991 Pinatubo eruption in the SKYHI GCM with a realistic Quasi-Biennial Oscillation. J Geophys Res 109(D03112). doi:10.1029/2003JD003699

Stenchikov G, Delworth TL, Ramaswamy V, Stouffer RJ, Wittenberg A, Zeong F (2009) Volcanic signals in oceans.
J Geophys Res 114(D16104). doi:10.1029/2008JD011673

Talley LD (1991) An Okhotsk Sea anomaly: Implications for ventilation in the North Pacific. Deep-Sea Res 38:S171S190

Talley LD (1993) Distribution and formation of North Pacific Intermediate Water. J Phys Oceanogr 23:517-537

Talley LD (2003) Shallow, intermediate, and deep overturning components of the global heat budget. J Phys Oceanogr 33:530-560

Trenberth KE, Caron JM (2001) Estimates of meridional atmosphere and ocean heat transports. J Climate 14:3433-3443

Whitworth III T, Peterson RG (1985) Volume transport of the Antarctic circumpolar current from bottom pressure measurements. J Phys Oceanogr 15:810-816

Whitworth III T, Kim S-J, Orsi AH, Nowlin WD (1998) Water masses and mixing near the Antarctic Slope Front. Antarctic Res Series 75:1-27

Yang F, Schlesinger ME (2002) On the surface and atmospheric temperature changes following the 1991 Pinatubo volcanic eruption: A GCM study. J Geophys Res 107. doi:10.1029/ 2001JD000373

Zanchettin D, Timmreck C, Graf H-F, Rubino A, Lorenz S, Lohmann K, Krüger K, Jungclaus JH (2012) Bi-decadal variability excited in the coupled ocean-atmosphere system by strong tropical volcanic eruptions. Climate Dyn 39:419-444

Zangenberg N, Siedler G (1998) Path of the North Atlantic Deep Water in the Brazil basin. J Geophys Res 103(C3): 5419-5428

Received Jul. 25, 2012

Revised Jul. 26, 2012

Accepted Sep. 13, 2012 